Montana Water Center Technical Working Group

\title{
EVALUATING IRRIGATION \\ EFFICIENCY: TOWARD A \\ SUSTAINABLE WATER \\ FUTURE FOR MONTANA
}
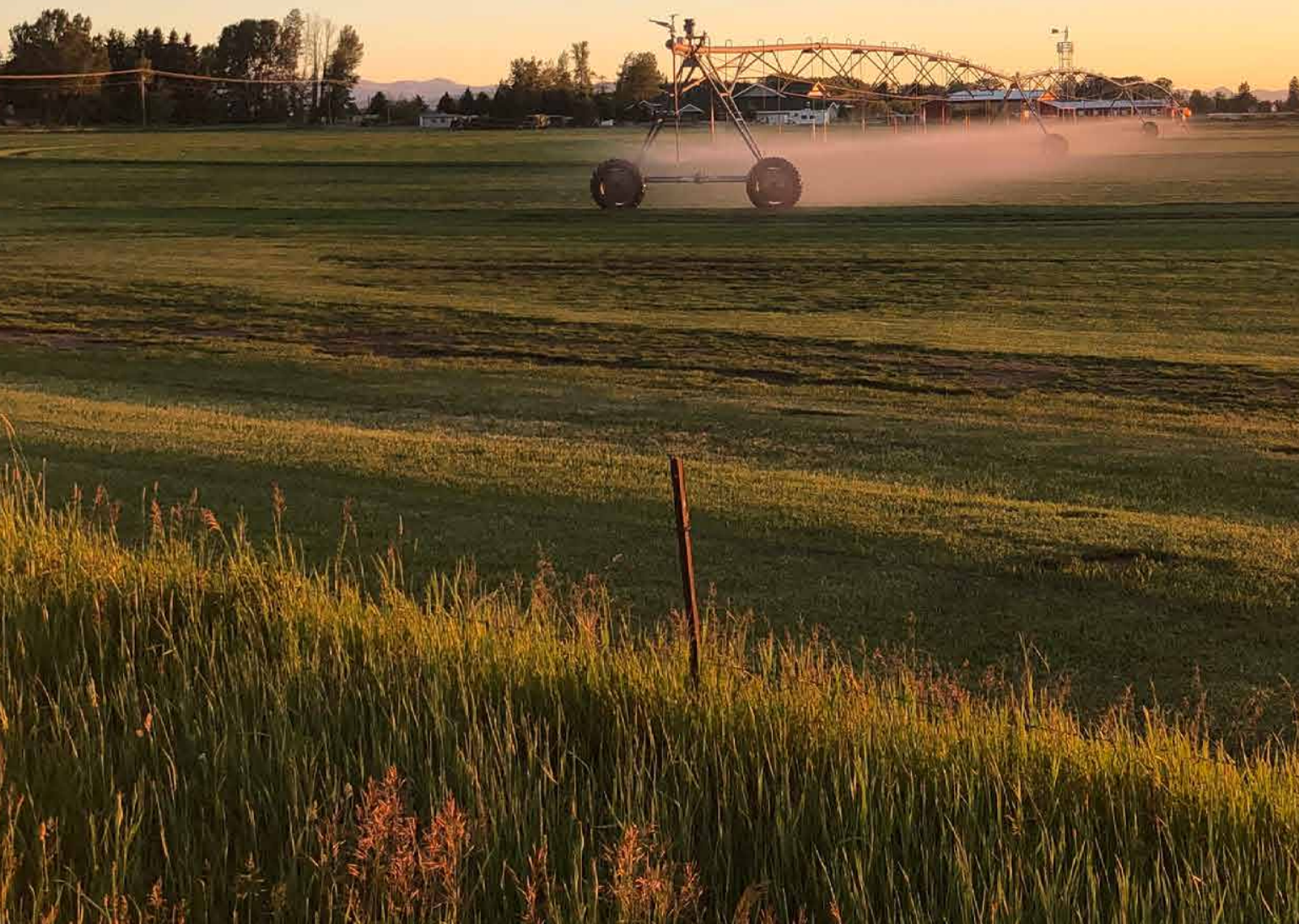

A publication of the Montana University System Water Center 


\section{Lead authors:}

Whitney R. Lonsdale, Montana Water Center, Montana State University, Bozeman, MT 59717

Wyatt F. Cross, Montana Water Center, Montana State University, Bozeman, MT 59717

\section{Contributing authors:}

Charles E. Dalby, Kintla Enterprises, Helena, MT 59601

Sara E. Meloy, Montana Department of Natural Resources and Conservation, Helena, MT 59601

Ann C. Schwend, Montana Department of Natural Resources and Conservation, Helena, MT 59601

The Montana University System Water Center is part of a nationwide network of university-based Water Resources Research Institutes and is housed at Montana State University (www.montanawatercenter.org). The primary goals of the Water Center are to support water research and education, and to provide accurate and unbiased information on Montana's most critical water issues. The Montana Water Center also serves as a connection point between the Montana University System and other water-focused entities and stakeholders in the state.
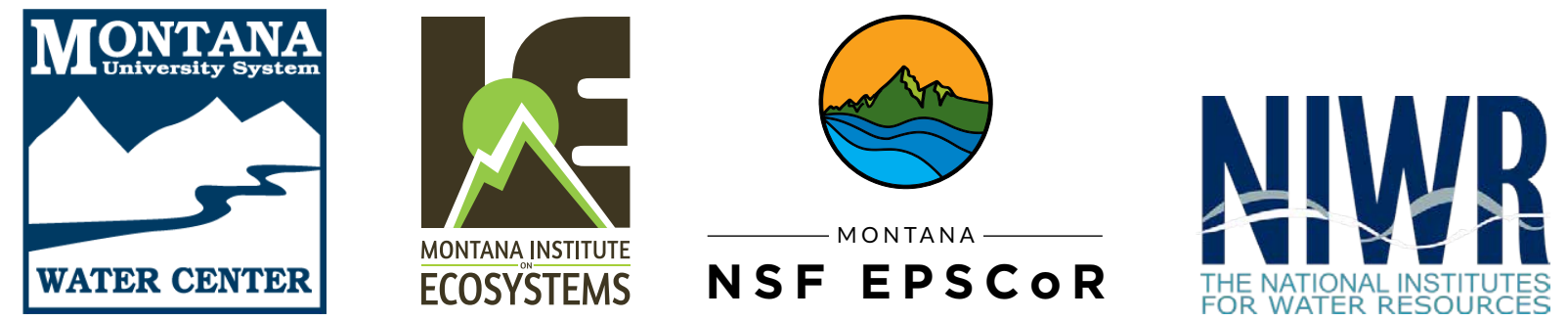

Published November 2020

Please cite this publication as: Lonsdale, W. R., Cross, W. F., Dalby, C. E., Meloy, S. E., Schwend, A. C., 2020. Evaluating Irrigation Efficiency: Toward a Sustainable Water Future for Montana, Montana University System Water Center, Montana State University, 42p., doi.org/10.15788/mwc202011 


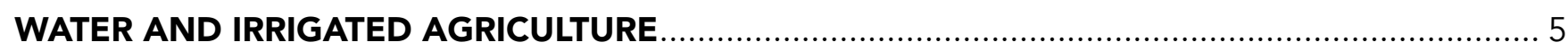

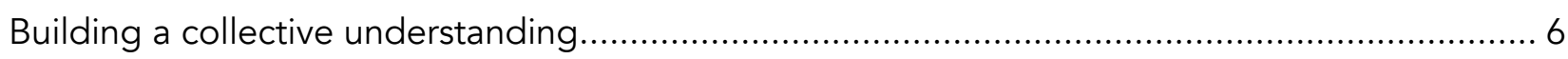

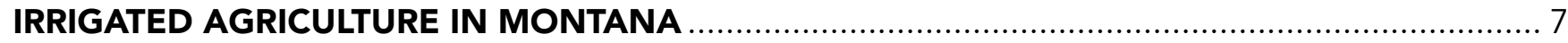

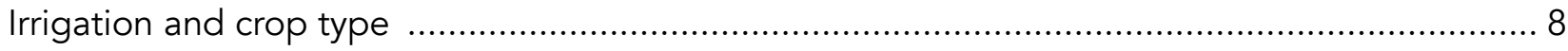

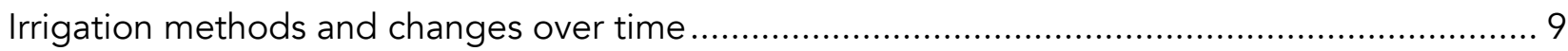

Motivating factors for converting to sprinkler irrigation .............................................. 10

Motivating factors for maintaining flood irrigation .......................................................... 11

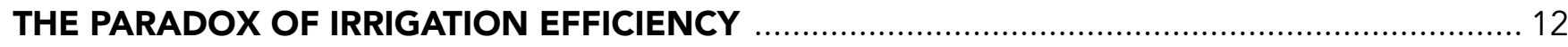

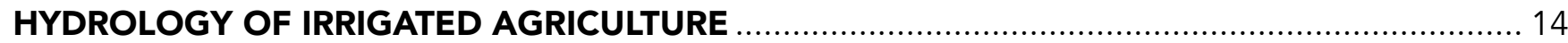

ASSESSING CONSEQUENCES OF CHANGING IRRIGATION METHODS ............................. 16

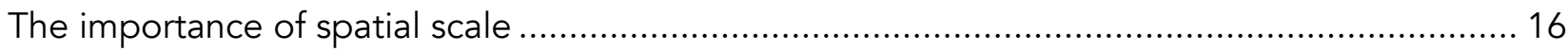

Irrigation influences the spatial and temporal availability of water .................................... 19

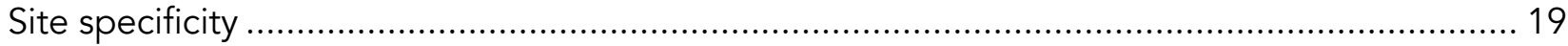

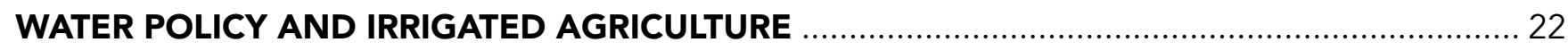

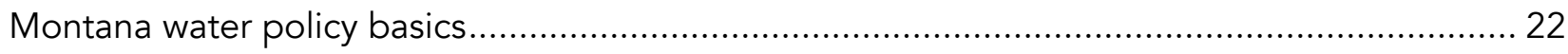

Water policy and changes in irrigation method ......................................................... 23

Case Study 1: U.S. Supreme Court decision for

the Tongue River Basin (Montana v. Wyoming) ......................................................... 24

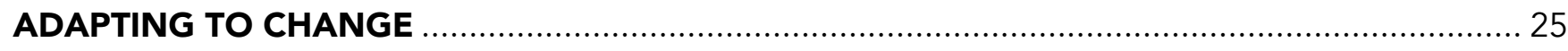

Montana's changing climate ............................................................................................ 26

Goal 1: Watershed-scale Irrigation Management and Water Budgeting …..................... 27

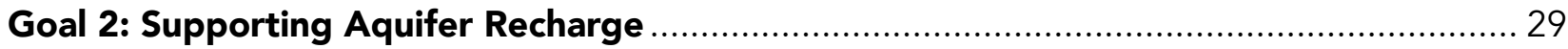

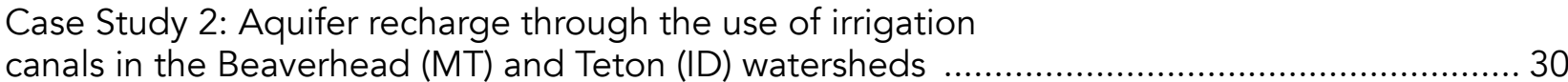

Case Study 3: Gold Creek: Maintenance of diverse irrigation

methods to optimize water supply in Gold Creek, MT ....................................................... 33

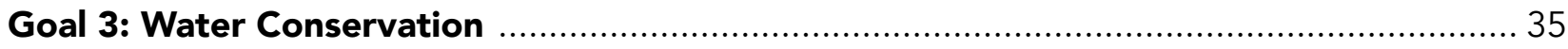

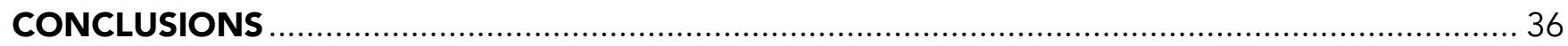

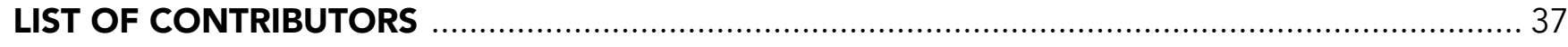

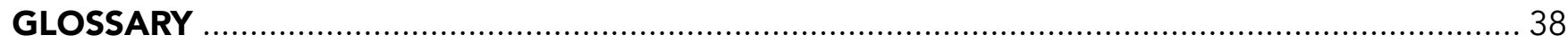

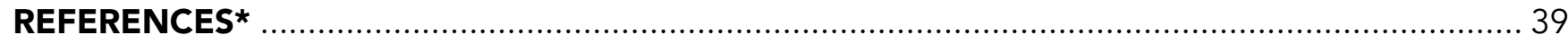

* Footnotes are lettered a-z throughout the text and citation references are numbered. 


\section{Figures, Tables, and Boxes}

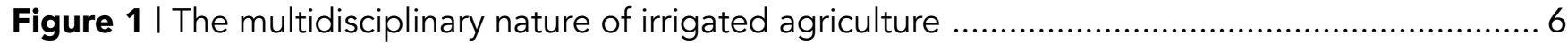

Figure 2 | Statewide irrigation consumption by 8 -digit hydrological unit ..................................... 8

Figure 3 | Conversion to sprinkler irrigation in Montana ................................................. 9

Figure 4 | Conversions from flood to sprinkler irrigation near Hamilton and Bozeman, Montana....... 10

Figure 5 | Pathways of water flow in irrigated agriculture ................................................... 15

Figure $\mathbf{6}$ | Spatial scale influences calculations of irrigation efficiency ...................................... 17

Figure 7 | Importance of flow regime to aquatic ecology .......................................................... 21

Figure 8 | Conceptual differences in flow regime as a result of irrigation management practices ...... 21

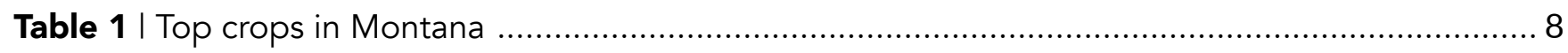

Table 2 | Potential outcomes of different irrigation and conveyance methods .............................. 13

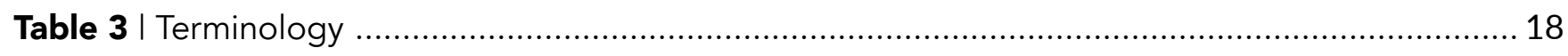

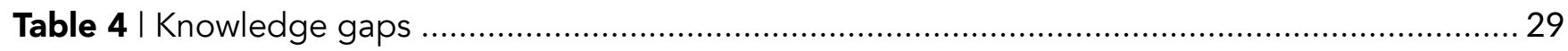

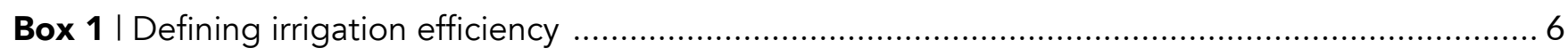

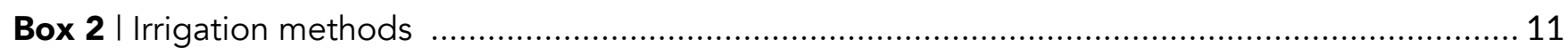

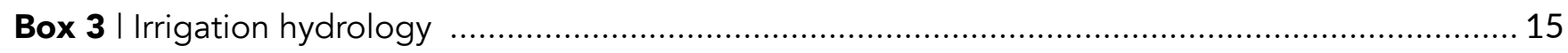

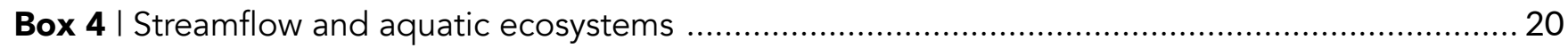

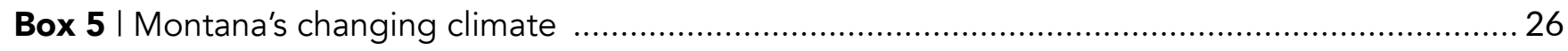


1 Irrigated agriculture is an essential part of Montana's history, culture, and economy, and it contributes substantially to regional and national food security. Irrigated agriculture also represents the largest consumptive use of water in Montana and changes in irrigation practice can thus profoundly influence water supply and availability.

Over the past 50
years, many producers across the West and in Montana have made changes to their irrigation practice and infrastructure in an effort to increase irrigation efficiency, defined as the ratio of water consumed by crops to diverted water (consumed water $\div$ diverted water).

3 Changes in irrigation technology to increase irrigation efficiency, including shifts from flood to sprinkler irrigation or the lining of canals, can provide significant on-farm benefits such as reduced labor and increased production. Such changes may have positive or negative consequences for streamflow and aquatic ecosystems and the difference depends on local site-specific hydrologic and geologic conditions and irrigation management decisions.

4. Changes in irrigation increase irrigation efficiency have not necessarily led to water conservation, and such changes may have unintended consequences for water supply and availability at a watershed scale.
5 A shift to sprinkler irrigation or the lining of canals can reduce seepage to groundwater; this seepage (aquifer recharge) may serve other purposes in the watershed such as maintaining streamflow during low flow periods, providing domestic and municipal water supply, and supporting downstream irrigators.

\section{Changes from flood to sprinkler irrigation can lead} to an increase in water consumption due to increased crop production and additional water use by junior water rights holders.

\section{While some changes to irrigation practice} influence water consumption, others alter the timing and location of water availability; understanding the difference is essential for effective management and planning.

\section{8} There may be scenarios in which the benefits of conversion to sprinkler irrigation - diverting less water and leaving more water in the stream at the time of diversion - outweigh the risks and potential impacts of increased consumption and reduced aquifer recharge.

\section{9} Consequences of changing irrigation methods differ from place to place based on site-specific factors such as land and soil characteristics, crop type, water management context, and individual decision-making. Place-based strategies that consider these site-specific factors will be essential for supporting or enhancing irrigated agriculture while balancing the many other demands on water supply.

\section{Transparent} measurement and monitoring of irrigation water, and the development of quantitative water budgets, will be essential in assessing hydrologic responses to changing irrigation methods and planning effectively for future water use.

\section{The amount of water naturally stored in our} watersheds is declining due to reductions in winter snowpack, floodplain disconnection, and shifts in irrigation methodology; irrigation infrastructure and management may offer opportunities for increased aquifer recharge and additional natural storage. Incentives are needed to support such opportunities.

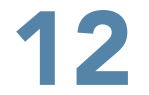

Water policy can either support or constrain strategies to balance water supply and demand in response to shifting irrigation methods, population growth, and changes in climate; meaningful discourse is needed to assess key policies that can support creative win-win solutions for agriculture, aquatic ecosystems, and other essential water needs.

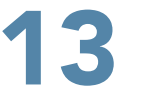

\section{Agricultural} decision-making is motivated by a broad spectrum of factors beyond profit maximization, including long-term operational viability, land management ethics, and maintenance of cultural identity. Policies, strategies, and incentive programs that consider the diversity of socio-cultural and economic motivators will be most effective.

\section{Irrigation water management can,} where desired, function as a tool to help communities achieve locally identified water objectives. 


\section{WATER AND IRRIGATED AGRICULTURE}

Water is our most valuable natural resource, and is used to support the demands of industry, agriculture, hydroelectric power generation, and municipalities. Water also sustains Montana's booming recreation and tourism economy and maintains the diverse freshwater ecosystems that provide natural goods and services and promote human well-being. As our population continues to grow, and the collective demand for water increases, it is imperative that we carefully assess how our water is used, as well as how changes in water distribution, management, and governance are likely to influence its availability in the future. This is especially important in the context of a changing climate.

Here, we focus on irrigated agriculture - specifically, the topic of 'irrigation efficiency' - because irrigation represents the largest consumptive use of water in the state $\left(\sim 67 \%^{1}\right)$. As a consequence, irrigation systems, and any changes therein, will have significant and lasting effects on how water moves across the landscape and through our river valleys, with important implications for agriculture, wildlife, policy, and society.

More than 150 years of irrigated agriculture has altered the natural water balance in many of Montana's river valleys. Prior to agricultural development, intact floodplains and large beaver populations maintained regular exchange between surface water and groundwater, and alluvial aquifers were widely distributed in river valleys. Over the past century and a half, thousands of miles of seeping irrigation canals, ditches, and saturated farm fields have created a new hydrologic system, which maintains alluvial ${ }^{a}$ aquifers but alters their geographic distribution and the timing of groundwater availability throughout the year. In addition to the maintenance of existing aquifers, irrigation has also produced new shallow aquifers, all of which soak up irrigation water and release it at a later time, potentially influencing streamflow. Thus, in areas with extensive flood irrigation, a novel pattern of human-influenced streamflow and groundwater hydrology has developed, and this pattern still exists today. Downstream water users, including irrigators, municipalities, fish and wildlife, recreationists, and individuals on wells, heavily depend on this legacy of agricultural activity and the many aquifers that are maintained or enhanced by irrigation.

Over the past 50 years, there has been a trend toward new and more efficient irrigation methods ${ }^{b}$ that result in a lower volume of water diverted for irrigation, a larger proportion of diverted water consumed by crops, and a smaller proportion of that diverted water seeping into the ground to recharge aquifers. Commonly referred to as increasing irrigation efficiency, (Box 1) these changes often lead to on-farm gains in profitability and can yield specific hydrologic and ecological benefits (Table 2). However, increased irrigation efficiency can also result in unintended consequences at the watershed level, including increased water consumption, reduced groundwater levels, and undesirable changes to surface water availability. ${ }^{c}$ To prepare for changing water regimes and to develop informed, adaptive, and place-based management strategies, it is critical that we consider the complex, watershedlevel implications of changes in irrigation efficiency.

\footnotetext{
${ }^{a}$ characterized by loose soil or sediment

$b$ Unless specified otherwise, the term "irrigation methods" includes practices and technology related to both the application and delivery (conveyance) of irrigation water.

$c$ Implications of changing irrigation methods discussed in this paper generally pertain to irrigated agriculture that is dependent upon and connected to river and alluvial aquifer systems, where exchange between shallow aquifers and surface water bodies takes place on relatively short time scales. The consequences of changing irrigation methods will be different in areas overlying deep aquifers that are not connected to river systems (such as the Ogallala Aquifer in the Great Plains).
} 


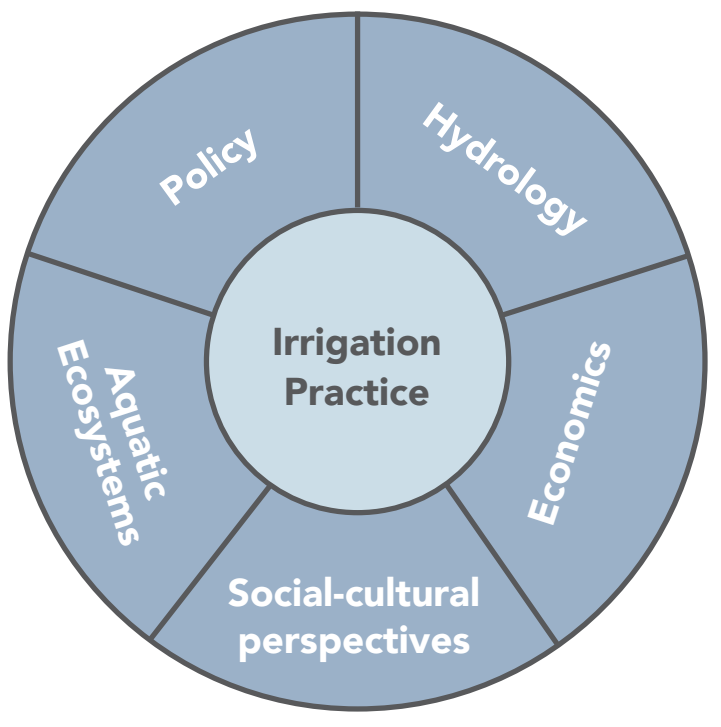

Figure 1 | The multidisciplinary nature of irrigated agriculture

\section{Building a collective understanding}

Irrigation is a vital tool for water management, and the topic of irrigation efficiency is multifaceted, requiring careful consideration of social, political, ecological, and hydrologic perspectives (Figure 1). In 2019-2020, the Montana Water Center convened a technical working group to better understand how changes in irrigation methods affect groundwater recharge, streamflow, and local and regional water supplies. The group comprised a diverse set of stakeholders including irrigators and irrigation managers, university scientists, agency scientists and managers, legislators, non-governmental organizations and tribal representatives (see List of Contributors, p. 37). A specific effort was made to represent different perspectives and areas of expertise. Through a series of webinars, workshops, meetings, and other outreach efforts, this group worked to (1) distill the core concepts and knowledge gaps associated with changes in irrigation efficiency, and (2) explore ways to mitigate any unintended consequences associated with such changes. In this document, we summarize the current state of knowledge and attempt to broaden understanding of this complex topic to support decision making by legislators, natural resource agencies, funding entities, and irrigators.

We begin with a brief overview of irrigated agriculture in Montana, including a short description of changes in irrigation method that have taken place over the past 50 years. Next, we explore the hydrology of irrigated agriculture in alluvial river valleys and what we know about the impacts of changes in irrigation method. We focus on irrigation from surface water sources, as surface water provides $99 \%$ of irrigation water withdrawals in Montana. ${ }^{d, 2}$ Next, we provide an overview of Montana water policy as it relates to changes in irrigation method, focusing on key aspects of policy that merit consideration in light of climate change and increasing water demand. Finally, we present creative ways to support the resilience of irrigated agriculture in Montana while addressing current and future changes in our water supply.

\section{BOX 1 DEFINING IRRIGATION EFFICIENCY}

Efficiency is often described as the capability of a specific effort to produce a specific outcome with a minimum amount of waste, expense, or unnecessary effort. Not surprisingly, increased efficiency is pursued as a goal in many arenas (e.g. economic markets, machinery, work flow, industrial processes). Traditional agricultural engineering has embraced the concept of irrigation efficiency when designing and evaluating irrigation projects.

In this context, irrigation efficiency (IE) is defined as the ratio of water consumed by crops to diverted water:

$I E=$ Consumed water $\div$ Diverted water.

If $50 \%$ of diverted water is consumed by the crop, then the field, farm or irrigation project is considered $50 \%$ efficient.

If $100 \%$ of diverted water is consumed, then the project is $100 \%$ efficient.

Total irrigation efficiency is determined by the combination of conveyance efficiency (delivered water $\div$ diverted water) and application efficiency (consumed water $\div$ applied water).
In the standard interpretation of efficiency, resources that are used but do not contribute to production are considered lost or wasted, and reducing this waste or loss is the goal of efficiency improvements. Herein lies the challenge of using this concept to assess irrigation water use (or water conservation) beyond the field scale. Water that is not delivered to the field or consumed in production is often not lost or wasted; it simply moves to another part of the watershed where it may serve another purpose, such as recharging aquifers or providing downstream water for agriculture or streamflow. In these cases, maximizing irrigation efficiency may have unintended consequences elsewhere in the system. In some situations, water not consumed by crops evaporates from soils, is consumed by non-crop plants, or flows to saline sinks, the ocean, or aquifers so deep they are considered inaccessible; in these cases, maximizing efficiency may lead to water conservation.

\footnotetext{
${ }^{d}$ Groundwater irrigation withdrawals have significant influence on hydrology in certain watersheds in Montana and, where this is the case, groundwater irrigation must be factored into water supply considerations and decision-making.
} 


\section{IRRIGATED AGRICULTURE IN MONTANA}

Irrigated agriculture has been an important component of the culture and livelihoods of Montana residents since the mid-19 $9^{\text {th }}$ century. The earliest documented irrigation was associated with the first homesteaders in the state wanting to take advantage of fertile river-valley soils and abundant surface water.

The expansion and growth of irrigated agriculture was linked to mining opportunities in the region, as well as the Homestead Act of 1862 and the Desert Land Act (Carey Act) of 1894, which incentivized homesteaders to settle the land by farming. Irrigators gradually settled Montana's alluvial river valleys, and new methods of water delivery, governance, and field application led to the nearly 7,500 irrigated farms and more than 20,000 miles of conveyance ditches and canals that exist today. Variation in irrigation development has resulted in a diversity of irrigation methods, including both gravity-based flood and sprinkler irrigation and more mechanized pump systems. A variety of irrigation management systems have also been developed, and today irrigation water is managed by individuals, groups of individuals, private irrigation companies, state and federal agencies, and federal or state-designated irrigation districts, all with varying levels of oversight, measurement, and cooperation. These activities have resulted in a productive and vibrant farm economy that is an essential part of Montana's $\$ 4.4$ billion agricultural industry. ${ }^{3}$ The land area allocated to irrigated agriculture is a small portion of the total cropland but accounts for a disproportionate share of the total agricultural production and farm revenues.

\footnotetext{
$e$ Conveyance refers to the collective network of canals, ditches and laterals that facilitate the transport of irrigation water between water sources and fields. In this paper, unless otherwise stated, we use the terms canal and ditch interchangeably to represent conveyance.
} 


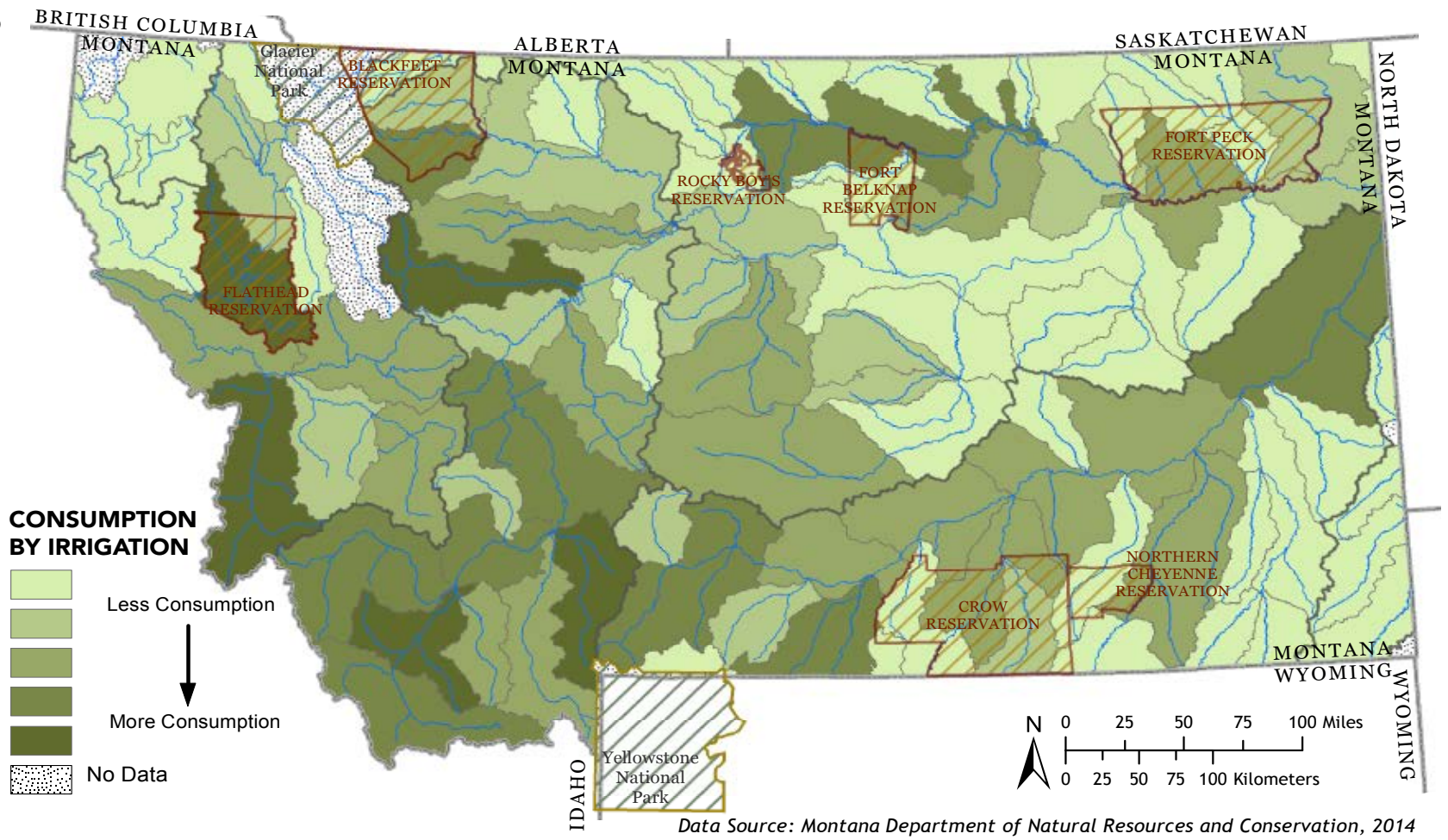

Figure 2 | Statewide Irrigation Consumption by 8-digit Hydrological Unit. (Montana State Water Plan')

\section{Irrigation and crop type}

A large variety of crops is grown on irrigated lands across Montana, but the dominant crops include alfalfa, hay, barley, wheat, corn, safflower, and sugar beets (Table 1). Crop type plays an important role in determining the timing and amount of irrigation water applied to fields because of variation in plant water demand, rooting depth, life cycle characteristics, and susceptibility to water stress. ${ }^{4}$ These differences also influence irrigator decisions about method and timing of water application and whether it is feasible or worthwhile to change or modify their infrastructure.

\section{TOP CROPS IN MONTANA}

\begin{tabular}{l|l|l|l} 
CROP & $\begin{array}{l}\text { \% OF TOTAL IRRIGATED } \\
\text { CROPS IN MT }\end{array}$ & $\begin{array}{l}\text { \% GROWN WITH FLOOD } \\
\text { IRRIGATION }\end{array}$ & $\begin{array}{l}\text { \% GROWN WITH SPRINKLER } \\
\text { IRRIGATION }\end{array}$ \\
\hline Alfalfa & $40 \%$ & $42 \%$ & $58 \%$ \\
\hline Grassland/pasture & $15 \%$ & $73 \%$ & $27 \%$ \\
\hline Other hay/non-alfalfa & $13 \%$ & $67 \%$ & $33 \%$ \\
\hline Barley & $10 \%$ & $35 \%$ & $65 \%$ \\
\hline Spring wheat & $8 \%$ & $32 \%$ & $68 \%$ \\
\hline Corn & $4 \%$ & $57 \%$ & $43 \%$ \\
\hline Winter wheat & $3 \%$ & $44 \%$ & $56 \%$ \\
\hline Sugar beets & $2 \%$ & $68 \%$ & $32 \%$ \\
\hline Canola & $1 \%$ & $5 \%$ & $95 \%$ \\
\hline Potatoes & $1 \%$ & $2 \%$ & $98 \%$ \\
\hline
\end{tabular}

Table 1 | Top Crops in Montana. The top ten irrigated agriculture crops in Montana by percent land area, and the proportion of each crop grown with flood and sprinkler irrigation. ${ }^{54}$ 


\section{ACRES CONVERTED TO SPRINKLER IRRIGATION}

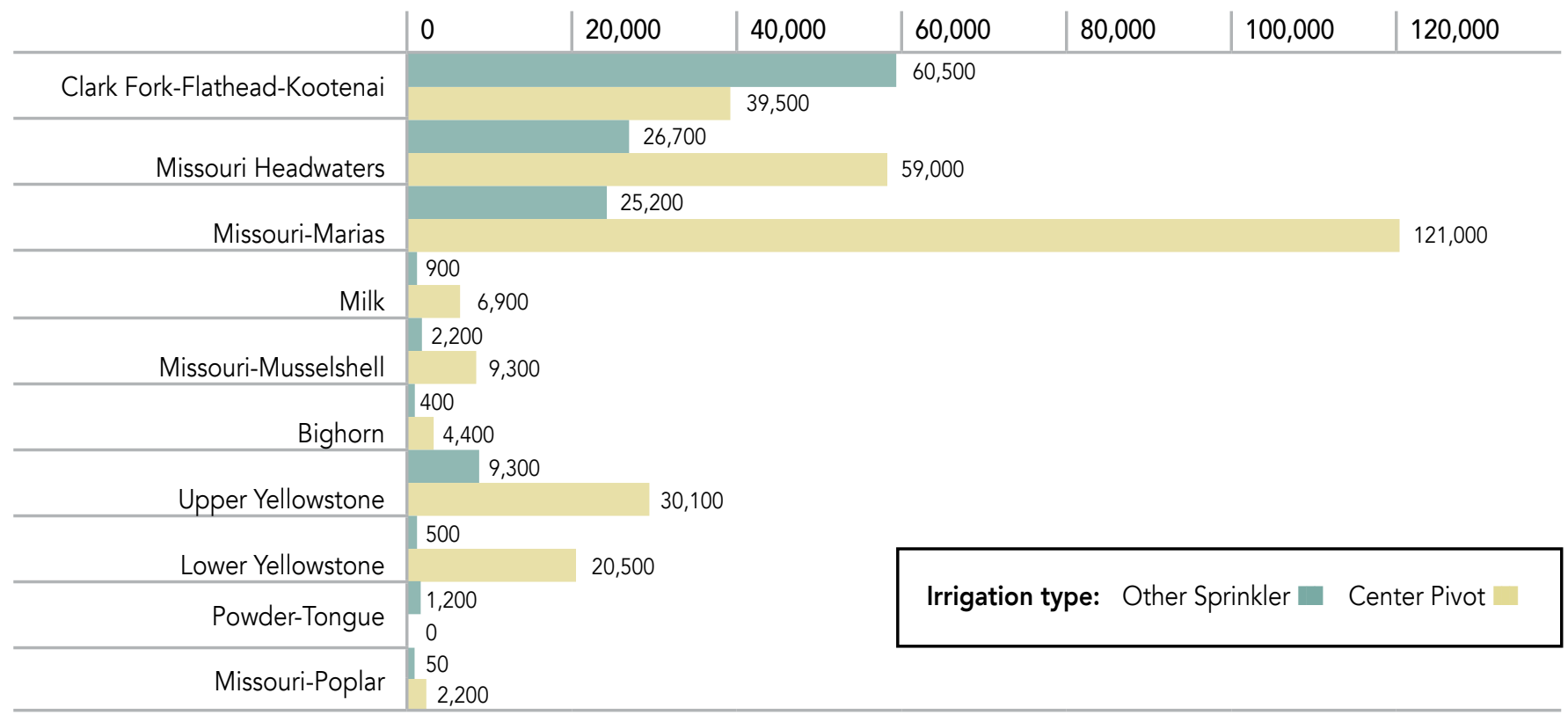

Figure 3 | Conversion to sprinkler irrigation in Montana by major watershed. A comparison of the Department of Natural Resources and Conservation Water Resource Survey (DNRC-WRS) mapping and the Department of Revenue Final Land Unit (DORFLU) classification in 2019 provides an estimate of the amount and geographic location of conversion from flood to sprinkler irrigation in Montana. ${ }^{54}$ This comparison is limited to the land area included in the mid-20th century DNRC-WRS. The analysis therefore captures proportional changes in irrigation method across Montana but may underestimate actual acreage converted to sprinkler.

\section{Irrigation methods and changes over time}

The early settlers relied on flood irrigation, which diverts water from the source (stream) through a canal to the farm, with a series of lateral canals to encourage the water to flow in sheets across a field, temporarily saturating everything along the way. This method of irrigation requires gravity, significant labor and handson management, and a large volume of diverted water to travel to the fields and beyond. Farm fields were typically uneven and water delivery was varied, with some spots getting saturated and others less so. After the turn of the century, the Pick Sloan Act of 1944 launched the development of large water projects and the establishment of cooperative irrigation districts. This era was marked by notable growth in the agricultural industry in Montana through the building of many federal dams and canal systems to supply irrigation water and provide downstream flood control.

Over time, increasing demands for water, concerns for water quality, and challenges in labor availability and cost compelled many irrigators to seek out ways to modernize their farm operations. In recent decades, one of the most widespread changes to irrigation methodology has been the conversion from gravity-based flood irrigation to more time- and labor-efficient mechanized and electric pump-based sprinkler irrigation (Box 2). ${ }^{f}$ Such conversions, often in the context of increasing irrigation efficiency, have allowed producers to more carefully match crop demands with applied water, increase their crop yields, improve water and soil quality, and significantly reduce farm labor. In addition, some individuals and irrigation districts have begun to line and seal the bottom of canals and ditches to prevent the seepage of water during its conveyance to farms.

Comparison of historic and 2019 surveys of irrigated land (Figure 3 ) shows that between the mid-20th century and 2019 , about $21 \%$ (or 420,000 acres) of mapped flood-irrigated land in Montana was converted to sprinkler irrigation; $70 \%$ was converted to center pivot $(290,000$ acres) and $30 \%$ was converted to other types of sprinkler irrigation (130,000 acres; Figures 3 and 4). Most of the conversion (80\%) has taken place in the headwater valleys of western Montana. About $2 \%(30,000$ acres) of flood irrigated land has been converted to urban and suburban uses-primarily housing, industrial, subdivision-near population centers. In 2019, of the nearly 2 million acres of irrigated agricultural land in Montana, $50 \%$ was flood irrigated, $36 \%$ was irrigated by center pivot, and $14 \%$ was irrigated by other sprinkler methods. In addition to development of new sprinkler irrigation since the mid-20th century, roughly 250,000 acres of land were developed for new flood irrigation.

$f$ There are many different types of gravity-based and mechanized irrigation methods, which, combined with variation in conveyance, leads to a broad array of irrigation systems. The authors recognize that categorizing irrigation as either 'sprinkler' or 'flood' is an oversimplification; but they found this limited characterization necessary given the scope and length of this publication. 


\section{Conversions from flood to sprinkler irrigation near Hamilton and Bozeman, Montana.}

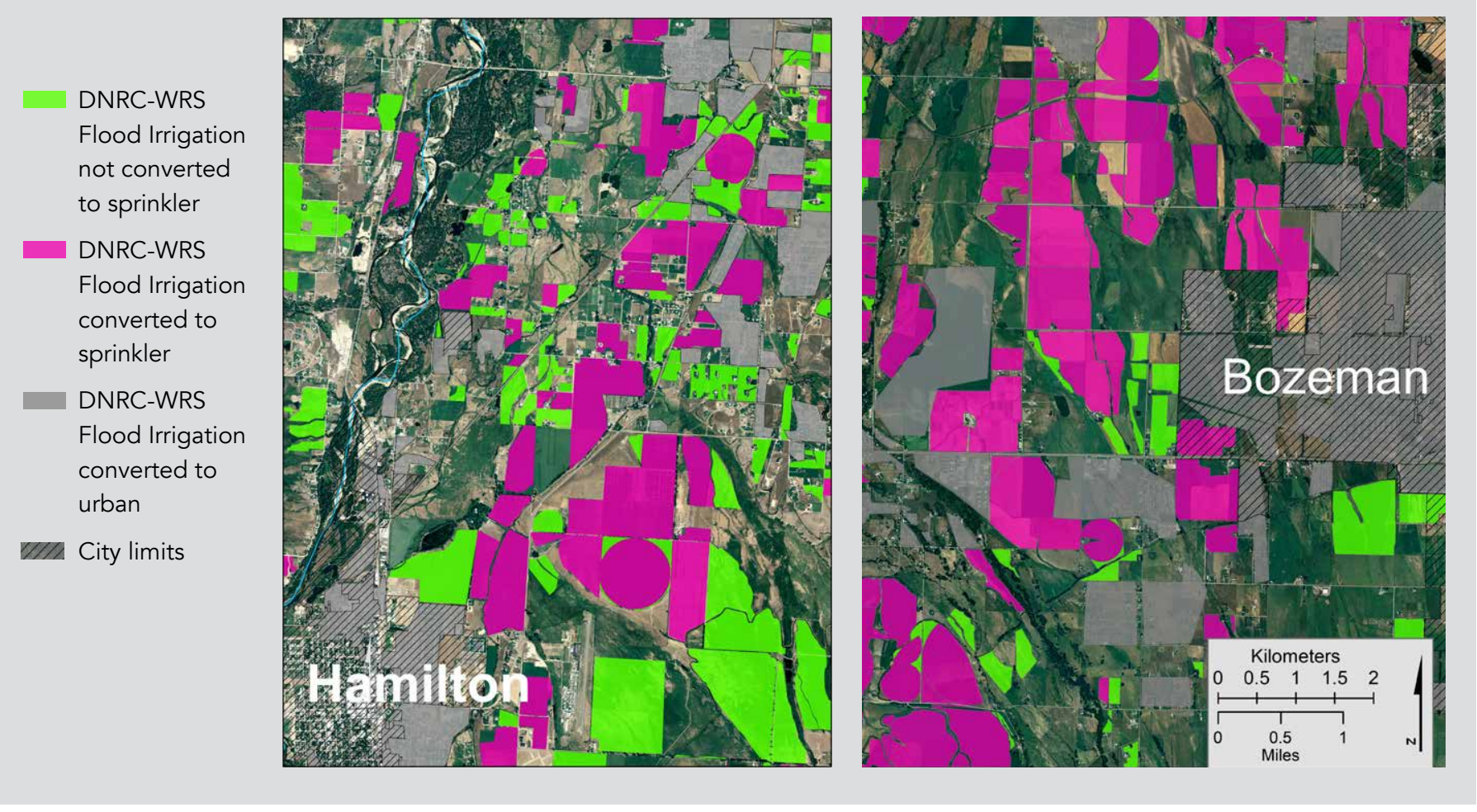

Figure 4 | Flood irrigated fields in Hamilton and Bozeman areas that were converted to sprinkler irrigation between the mid-20th century and 2019. Also shown are flood irrigated parcels not converted or converted to urban uses. Based on comparison of Montana Department of Natural Resources and Conservation Water Resources Surveys (1946-1971) and Montana Department of Revenue Final Land Unit Classification 2019. ${ }^{54}$

\section{Motivating factors for converting to sprinkler irrigation}

The physical characteristics of a field or farm, such as slope, soil type, and water availability, can dictate decisions around irrigation methodology and may necessitate the use of one particular method over another. Yet in many cases, multiple irrigation options exist, and the decision to change methods is driven by a combination of motivators, each with varying influence on the producers, canal companies, and government agencies involved.

- REDUCED LABOR Most flood irrigation is time and labor intensive, requiring producers and hired workers to be in the fields several times a day for weeks at a time. Gradual adoption of wheel line sprinklers and center pivots has steadily reduced time and labor costs. The benefits of this technology extend beyond the current generation of producers, as increased time and labor efficiency may make it more appealing and feasible for younger generations to stay in, or enter, the field of agriculture. More automated irrigation can also allow sufficient time to pursue off-farm employment opportunities to supplement household incomes.
- INCREASED CROP PRODUCTION Sprinkler irrigation technologies allow producers to apply water more accurately and precisely to crops, better matching crop water demand, and often leading to higher crop density or yield. Sprinklers may also allow producers to diversify and grow higher value products.

- ECONOMIC INCENTIVES Economic incentives provided to producers by state and federal agencies have supported the conversion to sprinkler irrigation across the West. In Montana, conversion was relatively slow to take hold, likely resulting from limited funding and few cost share opportunities. In recent years, the Farm Bill has enabled the Natural Resources Conservation Service (NRCS) to provide increased cost sharing and funding opportunities to producers for irrigation related projects.

- IMPROVED WATER QUALITY With the increasing use of agricultural chemicals and fertilizers in the 1960s, there was growing concern that excess water applied in flood irrigation provided a conduit for chemicals and nutrients to seep into groundwater or flow overland to surface water, leading to contamination. There are a number of 
physical and irrigation management-related factors that influence the degree of water quality impacts. However, with sprinkler systems, and even more so with center pivots, water, fertilizer and other agricultural chemicals can be applied more precisely, generally reducing the risk of contamination.

- INCREASED IRRIGATION EFFICIENCY AND PERCEIVED WATER SAVINGS A significant motivator for agencies in supporting the shift from flood to sprinkler irrigation has been to increase irrigation efficiency, i.e. to prevent seepage and runoff, and to maximize the proportion of diverted and applied water that is consumed by crops. The switch to sprinkler irrigation has meant that producers tend to divert less water from the source during times of active irrigation, potentially freeing up water for alternative uses. Thus, increased irrigation efficiency has often been equated with water conservation. However, while more water is left instream at the time and place of diversion, overall water consumption may actually increase due to the new sprinkler technologies and additional consumption by downstream users.

- AGRICULTURAL ECONOMICS The structural economics of the U.S. and world agricultural markets have created a persistent push toward ever-increasing mechanization and the consolidation of smaller farms into larger operations. These changes have made it more difficult to maintain the viability of farms and ranches with traditional, non-mechanized irrigation methods.

\section{Motivating factors for maintaining flood irrigation}

Many producers choose to maintain flood irrigation, and there are a variety of factors influencing this decision. ${ }^{5}$ Although flood irrigation requires a greater investment of time and labor relative to sprinkler irrigation, it involves significantly lower financial and technological inputs, even for the more precisely managed forms of flood irrigation such as gated pipe over leveled fields. Sprinklers, particularly center pivots, represent a large financial investment even if cost-share is available, and also require electricity to operate, adding additional cost and technical upkeep. Therefore, a producer must be confident in his or her ability to recover investment costs and power costs in order to view conversion as a viable option. Year-toyear water availability, general land productivity, and crop markets may all influence whether cost recovery seems feasible. In some cases, topographic and soil characteristics may influence choices in irrigation method. For instance, in areas with high salinity, it can be important to flush a certain amount of water through the soil to keep soil salinity low and producers may maintain flood irrigation to support this process. Finally, the desire to preserve traditional ranching methods and lifestyle may also factor into decisions to maintain flood irrigation.

\section{BOX 2 IRRIGATION METHODS}

FLOOD IRRIGATION - Water is applied and distributed over the soil surface through the use of gravity. Flood irrigation practices range from uncontrolled to highly controlled, with the use of dams, ditches, furrows, and/ or gated pipe to regulate the flow of water over lands that range from uneven pasture to carefully leveled fields.

SPRINKLER IRRIGATION - Method of providing rainfalllike irrigation to crops. Water is distributed through a system of pipes, often by pumping, and then sprayed into the air through sprinklers.

- Hand line irrigation - Developed in the 1930s, hand line systems were the first move away from flood irrigation. Hand lines consist of irrigation pipe laid along the ground with sprinklers placed at set intervals. Lines must be moved by hand across a field.
- Wheel line irrigation - Wheel line (or wheel move) sprinklers are portable irrigation systems consisting of a lateral pipe attached to large wheels, with sprinklers placed at set intervals along the pipe; a power mover at the center of the pipe moves the line across a field.

- Center pivot irrigation - Invented in 1948, center pivots are irrigation pipes supported by trusses and mounted on wheeled towers that make a mechanized circuit around a field. Sprinkler nozzles are placed at set intervals and can be placed at varying heights from the ground. Modern versions are highly automated and can also be used to apply fertilizer and other agrochemicals. 


\section{THE PARADOX OF IRRIGATION EFFICIENCY}

\section{While there are many obvious benefits} of sprinkler irrigation, there is increasing recognition that conversion to sprinkler irrigation or the lining of canals may not always lead to reduced water use or consumption. In fact, a growing number of studies have shown that shifts to sprinkler irrigation can lead to increased water consumption, along with the gradual decline in alluvial groundwater levels, especially when these changes are considered at a larger watershed or basin scale. ${ }^{6-9}$

Mechanized sprinkler irrigation allows a more precise match between farm water application and crop water requirements, more consistent application of water throughout the irrigation season, and more uniform coverage, all of which can increase crop production. In turn, increased crop production (assuming the same crop type) leads to increased water consumption because of a direct correlation between crop yield (plant growth) and water consumption. Sprinklers may also enable producers to exercise their full water right on one or more fields more often due to time-saving mechanization and reduced labor costs, or irrigate acreage that was unproductive under flood irrigation, e.g., raised or sloped land. With the ability to apply water more precisely and more consistently, producers may also choose to fallow fields less often, or to grow more water-intensive crops. Moreover, in contrast to flood irrigation methods, sprinkler pumps can remove water from the source or canal at lower flows; consequently, a producer may be able to appropriate water more consistently and over a longer duration within the irrigation season. Finally, if more water is left in the ditch or stream early in the season due to conversion to sprinklers, downstream junior water users may be able to appropriate and consume more water than they had previously, leading to increased consumption at a watershed scale.

The influences of changes to irrigation practice on total water consumption have not been well quantified in Montana, with the exception of a few cases.

The landmark Supreme Court decision Montana v. Wyoming, which acknowledged that conversion to sprinkler irrigation in Wyoming led to increased water consumption and reduced return flows to the Tongue River and downstream irrigators in Montana (Case Study 1). A study in the Upper Missouri Headwaters Basin found increased riparian dryness along nearly half (42\%) of the river reaches, and those sections with a drying trend had seen a greater land area converted to center-pivot irrigation than those with no drying trend. ${ }^{10}$ Other examples from the western US suggest that upgrades to irrigation infrastructure can lead to higher water consumption. For instance, conversion from flood to sprinkler irrigation in the Salt River watershed in Wyoming increased average hay production from 1.6 to 2.1 tons per acre ${ }^{11}$; in New Mexico, drip-irrigated fields had higher rates of production (8-16\%) and water consumption than flood irrigated fields growing the same crop. ${ }^{12}$ In addition, some efforts to reduce water consumption have unexpectedly led to higher consumption. In Western Kansas, irrigators switched from center pivots to dropped nozzle irrigation to reduce water use but inadvertently increased water consumption due to changes in crop choice, fallow practices, and a general increase in water use per unit of land area. ${ }^{13}$ Although increased consumption with more efficient irrigation may not always occur, this topic clearly merits further investigation and quantification in Montana. 


\section{POTENTIAL OUTCOMES OF DIFFERENT IRRIGATION AND CONVEYANCE METHODS}

\begin{tabular}{|c|c|c|}
\hline $\begin{array}{l}\text { TYPE OF } \\
\text { IMPACT }\end{array}$ & FLOOD IRRIGATION ${ }^{\dagger}$ OR UNLINED CANALS ${ }^{\dagger \dagger}$ & SPRINKLERS ${ }^{\dagger}$ OR LINED CANALS OR PIPES ${ }^{\dagger \dagger}$ \\
\hline Economic & $\begin{array}{l}\text { - Labor and time intensive } \\
\text { - Low power costs }{ }^{\dagger} \\
\text { - Increased potential need to add nitrate } \\
\text { to soil due to leaching } \\
\text { - Annual canal maintenance required }\end{array}$ & $\begin{array}{l}\text { - Lower labor and time intensity }{ }^{\dagger} \\
\text { - Increased power costs }{ }^{\dagger} \\
\text { - High initial investment } \\
\text { - } \text { Maintenance costs } \\
\text { - Reduces application rates and cost for fertilizers and other } \\
\text { - } \text { agricultural chemicals }{ }^{\dagger} \text { (due to precision application by sprinklers) } \\
\text { - Increases ability for additional harvest }{ }^{\dagger} \\
\text { - Increases ability to irrigate sloped fields }{ }^{\dagger} \\
\text { - Increases ability of some producers to earn income from } \\
\text { off-farm employment }^{\dagger}\end{array}$ \\
\hline $\begin{array}{l}\text { Water } \\
\text { Supply }\end{array}$ & $\begin{array}{l}\text { - Recharges aquifer } \\
\text { - Supports groundwater contribution to } \\
\text { streamflow } \\
\text { - Requires more water diverted from } \\
\text { streams/rivers (compared to pivot/pipe) } \\
\text { - Reduces spring peak streamflow }\end{array}$ & $\begin{array}{l}\text { - Reduces aquifer recharge } \\
\text { - Reduces groundwater contribution to streamflow } \\
\text { - Leaves more water instream at the time and place of diversion } \\
\text { - Potential increase in consumptive use at watershed scale }\end{array}$ \\
\hline $\begin{array}{l}\text { Water } \\
\text { Quality }\end{array}$ & $\begin{array}{l}\text { - Leaches nitrates from the soil } \\
\text { - Results in fertilizer runoff into streams and } \\
\text { leaching of fertilizer into } \mathrm{GW}^{+} \\
\text {- Provides cooling effect on summer } \\
\text { stream temperatures due to groundwater } \\
\text { contribution to streamflow }\end{array}$ & $\begin{array}{l}\text { - Reduction in leaching of nitrates }{ }^{\dagger} \\
\text { - Reduced contribution of agricultural chemicals to surface and } \\
\text { groundwater } \\
\text { - Reduced sedimentation of surface } \text { water }^{\dagger} \\
\text { - Increase in summer stream temperatures due to reduced } \\
\text { groundwater contribution to streamflow }\end{array}$ \\
\hline $\begin{array}{l}\text { Ecological } \\
\text { (also see } \\
\text { Box 4) }\end{array}$ & $\begin{array}{l}\text { - Maintains natural and/or incidental wetlands } \\
\text { - Provides important migratory bird habitat }{ }^{\dagger} \\
\text { - Reduced spring peak flow results in: } \\
\text { - Reduced numbers of young cottonwood } \\
\text { trees } \\
\text { - Impacts on fish habitat } \\
\text { - Impacts on channel maintenance } \\
\text { - Higher diversion rates may negatively impact } \\
\text { stream connectivity }\end{array}$ & $\begin{array}{l}\text { - Reduction in natural and/or incidental wetlands } \\
\text { - Higher spring peak flows result in: } \\
\text { - Increased numbers of young cottonwood trees } \\
\text { - Improved fish habitat } \\
\text { - Improved channel maintenance } \\
\text { - Lower diversion rates may improve stream connectivity }\end{array}$ \\
\hline
\end{tabular}

Table 2 | Generalized Impacts of Flood and Sprinkler Irrigation and Unlined and Lined Conveyance Methods. The outcomes listed are generalized and will not apply to all settings. Additionally, impacts are likely to vary considerably among individual systems using the same irrigation or conveyance method, depending on the hydrogeological setting and management context (see Site Specificity section, p. 19). The descriptions of outcomes are intended to be value-free, as the desirability is relative to individual or watershed goals. Unless otherwise specified, outcomes are relevant to both the irrigation and the conveyance method listed at the top of each column. Also see Stanley and Roberts, 2008. ${ }^{14}$ 


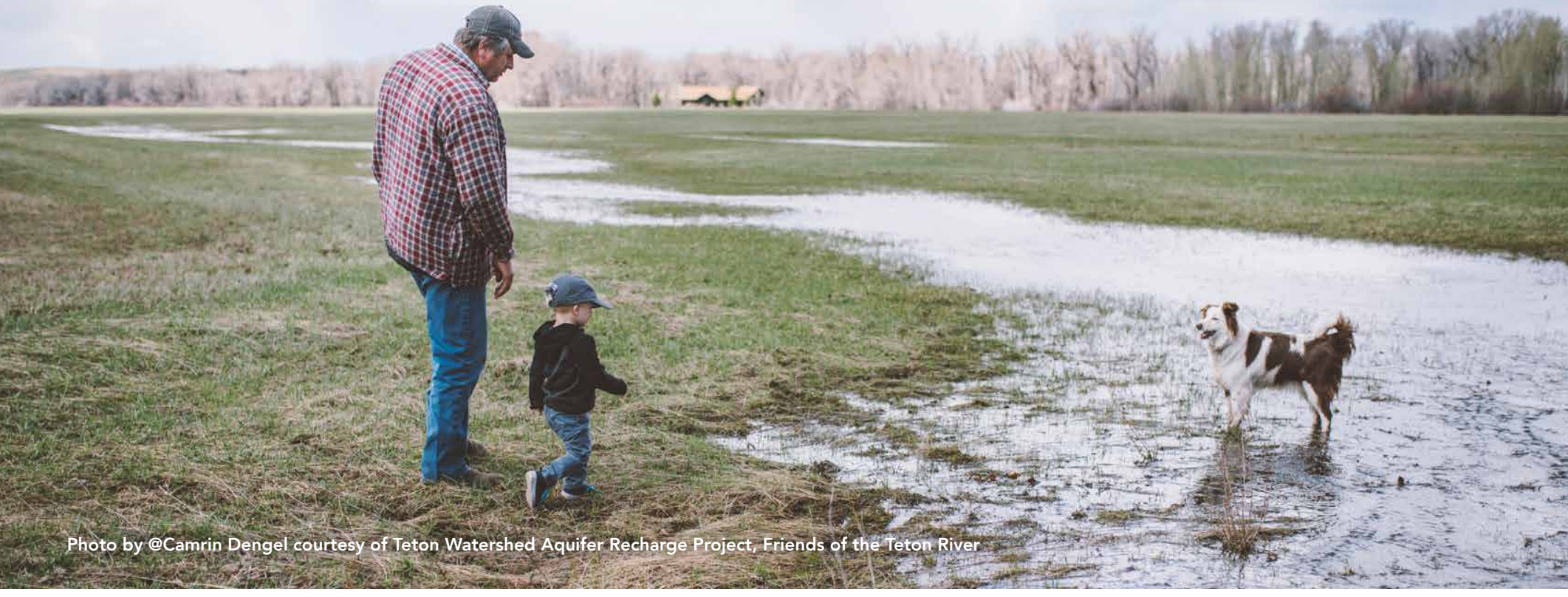

\section{HYDROLOGY OF IRRIGATED AGRICULTURE}

\section{With 10.5 million acre-feet of water per year diverted for irrigation, and 2.6 million acre- feet of that water consumed by crops, it is important to understand what is happening with the nearly 8 million acre-feet of water that is diverted but not consumed. Although this water has historically been considered a loss or a product of inefficiency, it has nonetheless come to play a critical role in the hydrologic regimes of our present-day irrigated valleys (Figure 5 and Box 3).}

In irrigated valleys in central and western Montana, individual parcels of land such as irrigated fields, subdivisions, and municipalities are hydrologically connected by surface water systems (streams, rivers, irrigation ditches and canals) and by the aquifer that underlies the watershed. Thus, the spatial and temporal variation in surface water supply is inextricably linked to groundwater. Recognition of this connection has grown in Montana over the past 50 years and in $2007^{15}$ the state reinforced the 'conjunctive' management of groundwater and surface water as a single resource and began requiring acknowledgement of this status in any water resource decision-making. Groundwater and surface water naturally interact in riparian systems as water moves between shallow aquifers and rivers and streams, and groundwater plays a crucial role in sustaining streamflow throughout the year. About half of the total annual flow in typical Montana streams is supported by groundwater, ${ }^{1}$ and some portion of this is influenced by irrigation.

Irrigation ditches and canals interact with the aquifer in similar ways to a stream or river: water can seep from a ditch or river to the aquifer, contributing to aquifer (groundwater) recharge; water can also flow from the aquifer to the ditch or river, bolstering flow through aquifer discharge. Irrigation ditches, if unlined, generally increase groundwater recharge in a watershed. Diverted water flowing through the vast network of irrigation ditches in a given watershed spreads surface water over a large geographic area and results in greater recharge than would take place if water flowed only in current riverbeds or stream channels. 9 Water applied to a farm field in excess of what is consumed by plants, and which does not evaporate, also seeps into the ground and contributes to aquifer recharge. Much of this groundwater recharge from fields and ditches in turn supports surface water streamflow when aquifers discharge into streams and rivers. Because there is a lag time between aquifer recharge by irrigation and aquifer discharge to surface water, this can be especially important for bolstering streamflow in the low-water months of the year.

$g$ Prior to human settlement, fully connected floodplains and large populations of beaver and the consequent changes to hydrology may have had a similar effect on aquifer recharge. 


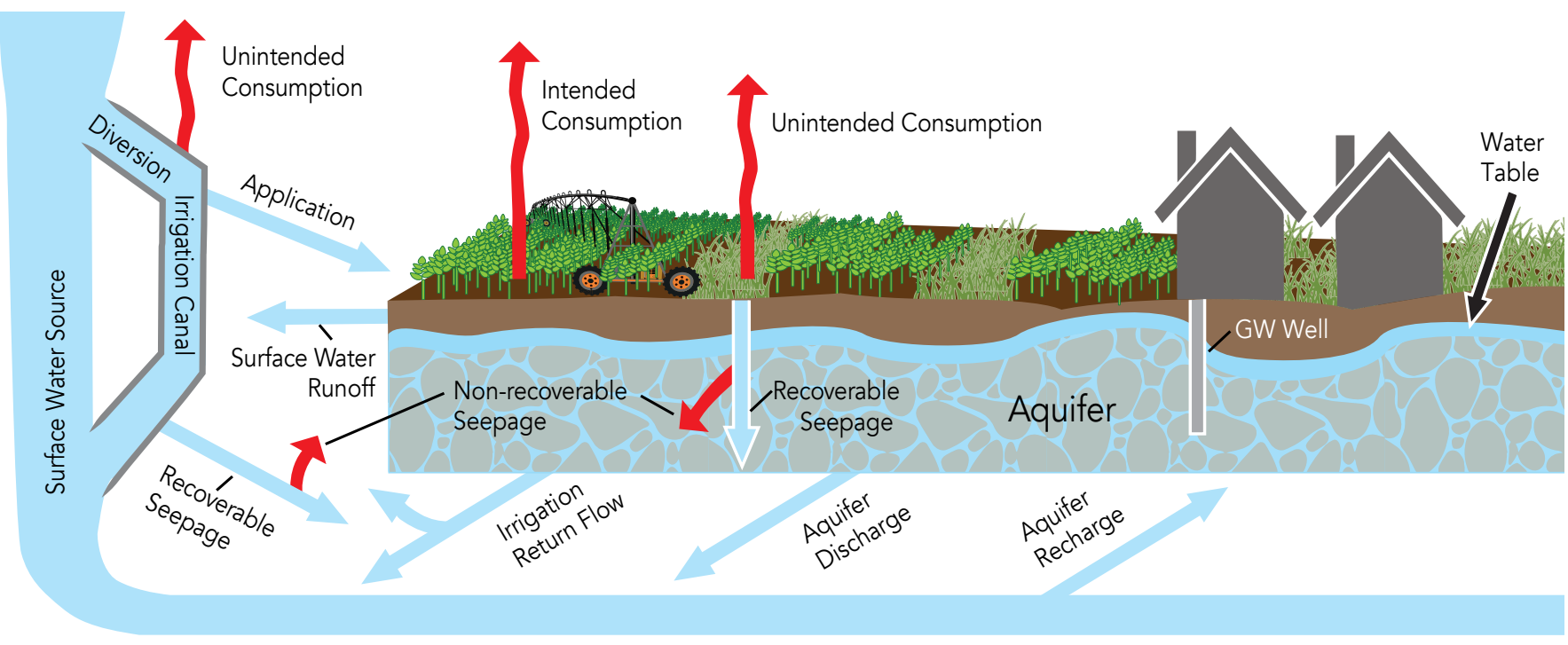

Figure 5 | Pathways of water flow in irrigated agriculture

\section{BOX 3 IRRIGATION HYDROLOGY}

Figure 5 portrays pathways of water flow in an irrigated agriculture system, including a surface water source (stream or river), an irrigation canal, an irrigated field, domestic buildings/homes on a well, and the alluvial aquifer that underlies the entire system. We use contemporary agricultural engineering terminology ${ }^{16,17}$ that focuses on the fate of water to describe pathways of water in an irrigated basin; this framework avoids value implications (e.g. farm loss, beneficial consumption, efficiency) and forms the basis for hydrologic tools, such as a water budget, that can be used to understand effects of conversion on local and downstream hydrology.

Water that is diverted from the surface water source has one of two fates. It either makes it to the place of use (i.e., application on the farm or field) or it doesn't. If water does not make it to the place of use, it either (a) remains in the ditch and ends up in a pond, wetland, or back in the original source, $(b)$ is unintentionally consumed via evapotranspiration in ditches (i.e.,

unintended consumption), or (c) seeps into the ground as canal recharge. Much of the water that seeps into the ground enters the aquifer and may become available (recoverable seepage) for subsequent downstream use. $^{h}$ The specific fate of water that does not make it to the place of use is strongly influenced by how water is delivered to the farm, including whether it is by pipe or ditch, and if and to what extent the ditches are lined. Additional characteristics of the conveyance system, such as length, adjacent vegetation, maintenance history, underlying geology, and elevation relative to the water table, all play a role in determining the proportion of diverted water that makes it to the farm. It is important to note that the amount of water delivered to the farm may change over the growing season depending on water supply conditions, priority of a water right, and the frequency and extent of crop harvest on an individual farm.

Once water is delivered to the farm, it either (a) is consumed by evapotranspiration of crops (i.e., intended consumption) or evapotranspiration from soils, sprinklers, and non-crop plants (i.e., unintended consumption), (b) flows overland and rejoins a surface water body, or (c) seeps into the ground. Much of the water that seeps into the ground makes its way into the aquifer, recharges groundwater, and can contribute to irrigation return flow ${ }^{i}$ and subsequent downstream use (recoverable seepage). A small percentage of seepage may percolate to such deep aquifers it is not reasonably recoverable, ${ }^{18}$ or may become too saline or contaminated by agricultural chemicals or fertilizers to be considered reusable (non-recoverable seepage). ${ }^{j}$ The amount of water consumed by crops is influenced by various environmental factors (e.g., weather, soil type) and farm practices (e.g., crop or seed type, method of application). Consumption by non-crop plants or evaporation from fields or sprinklers is influenced by crop phenology/timing, crop density, weed management, and the environmental factors listed above. The intended and unintended consumption both contribute to total consumptive use, which, combined with nonrecoverable seepage, represents the total quantity of water that is unavailable for reuse (colored red in Figure 5).

\footnotetext{
${ }^{h}$ A small portion of this seepage may not make it into the focal aquifer and is thus referred to as non-recoverable seepage; this portion is functionally removed from the watershed (i.e., unavailable for reuse in the watershed).

${ }^{i}$ That part of the diverted flow that is not consumptively used and is returned to its original source or other body of water. See Glossary for Montana's legal definition of return flow. $j$ From a conservation of mass standpoint, water is only physically lost from a watershed through evapotranspiration or deep groundwater percolation into an aquifer system that does not result in discharge back to the watershed in some reasonable time frame. Degraded water is lost from the watershed from a functional, but not a physical, standpoint.
} 


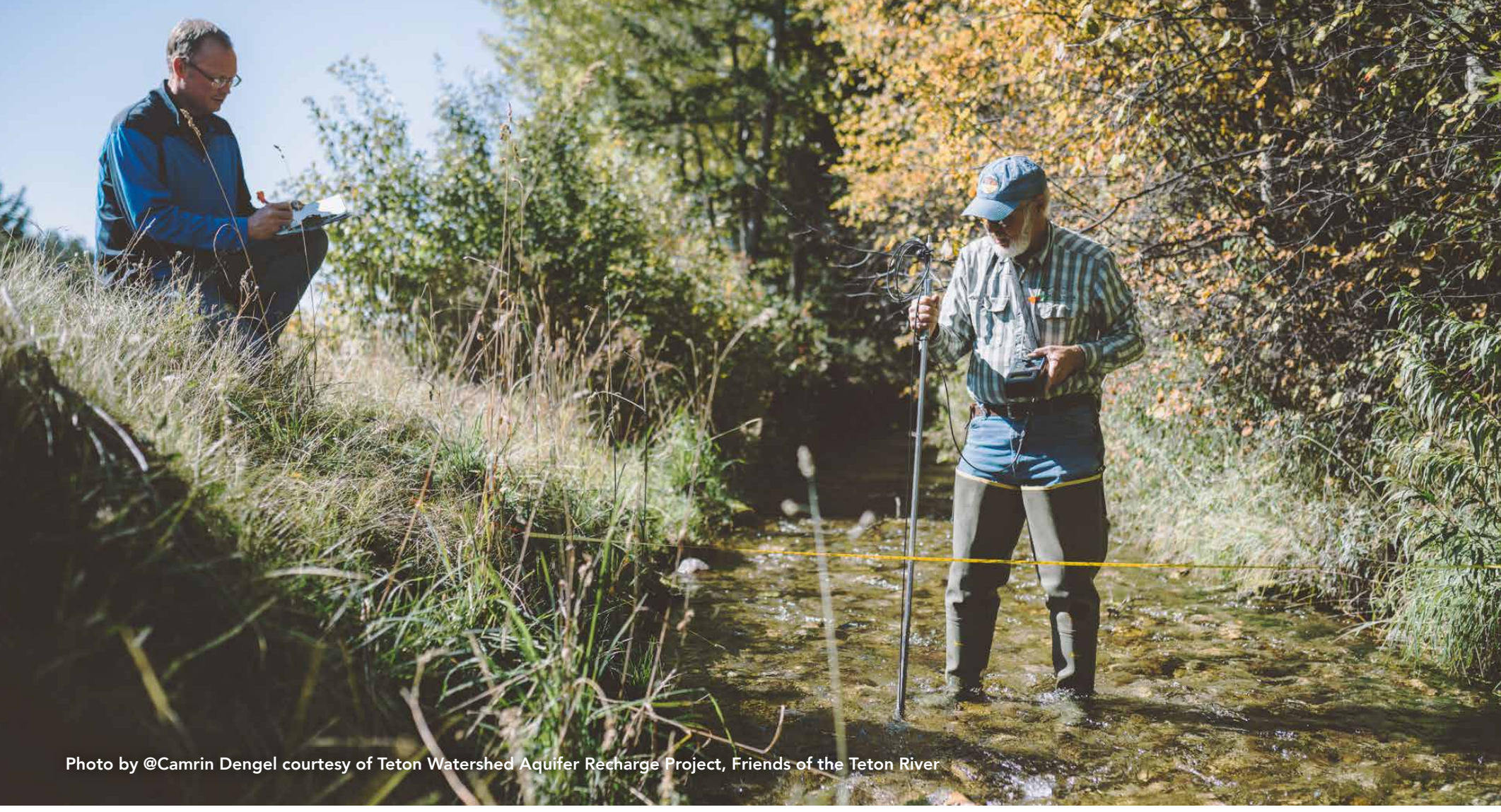

\section{ASSESSING CONSEQUENCES OF CHANGING IRRIGATION METHODS}

\section{Moving from hydrologic concepts to the} implications of changing irrigation methods requires consideration of spatial and temporal scale and a wide variety of sitespecific factors.

\section{The importance of spatial scale}

Spatial scale refers to the geographic extent being considered, whether it is a field, farm, or a watershed. Clearly delineating the scale of the system in question influences the way hydrologic processes or pathways are defined or described. For example, the traditional term conveyance loss refers to water diverted from a river into a ditch that does not make it to a field. To clearly understand and quantify how much water is actually 'lost' (i.e., unavailable for further reuse), it is essential to define the scale of the system in question. If the scale of the system is defined as a short stretch of canal, seepage from this canal can accurately be considered a loss from that system. However, if we define the scale as a larger irrigation district or a watershed, most of the water that seeps into the aquifer is not lost, it has simply moved to a different part of the hydrologic system and may be available to support other uses such as downstream irrigation or streamflow that enhances recreation or fisheries. The same is true for water applied to a field in excess of what is used for crop transpiration: the fraction of applied water that remains as liquid water and seeps into the underlying aquifer is not lost, it has also simply moved within the system. Thus, if a watershed is the system in question, water is only truly removed when it evaporates, is transpired during plant growth, flows out of the watershed, or is impaired to the extent that it is not considered viable for reuse.

Changes in irrigation and conveyance technology are often proposed with the goal of reducing water losses and thereby saving water for other purposes. However, if field or canal seepage was already serving the purpose of aquifer recharge, and that water was being reused downstream (as is the case in many watersheds in Montana), then the water was not actually lost in the first place. Thus, much of the time, shifts in irrigation technology are not truly 


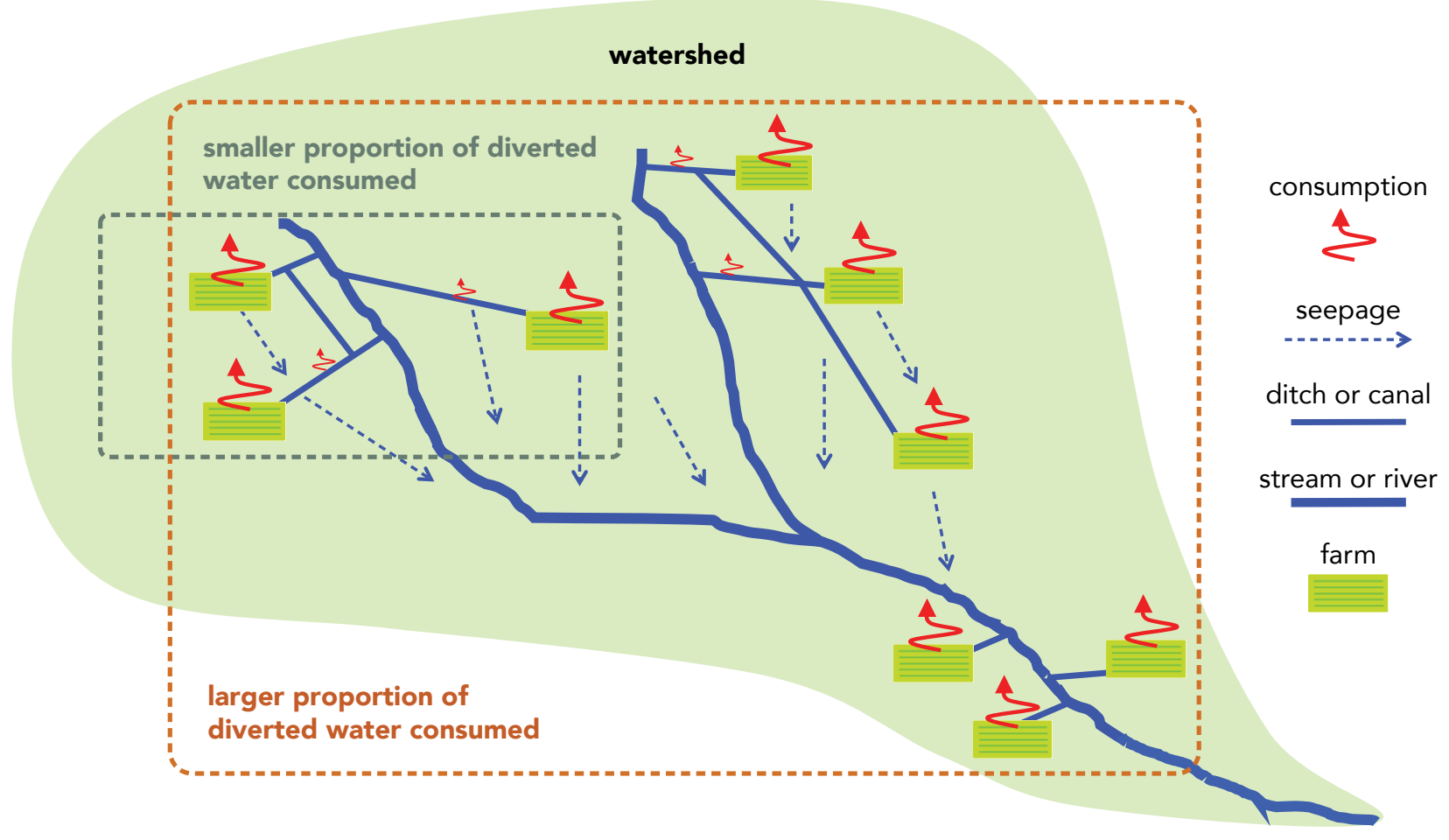

FIGURE 6 | Spatial scale influences calculations of irrigation efficiency. Defining the spatial scale or boundary of a system affects the calculation of irrigation efficiency, i.e., the proportion of diverted water that is eventually consumed. If the defined system is a single farm or small group of farms (grey dashed boundary), a substantial proportion of the diverted water - especially under flood irrigation - may not be consumed by crops within that system. Water not consumed may seep into groundwater and flow downgradient, becoming available to water users at lower positions in the watershed. Due to the potential for water reuse, when the larger watershed is considered (orange dashed boundary), a much greater proportion of the total diverted water may be consumed.

saving water, they are simply changing the timing and location of its availability in the larger watershed, ${ }^{k}$ which may also be an important goal (Box 3).

How we calculate and understand irrigation efficiency also depends on the spatial scale being considered. ${ }^{19,20}$ For example, if water is diverted to a farm from a stream or river and only half of that volume is consumed by crop transpiration, this would traditionally be considered a $50 \%$ irrigation efficiency (Figure 6). However, water not consumed on one farm may pass through surface water or the shallow aquifer to be reused and consumed by crops on a downstream farm. In this way, multiple farms within a watershed that are each $~ 50 \%$ efficient can together lead to an irrigation system in which a much larger percentage of the water diverted is consumed. This increase in efficiency is generally proportional to the volume of water reuse within the system.

It is important to emphasize that the relevant spatial scale to consider in calculations of irrigation efficiency is dependent upon the question being considered, and that efficiency at one scale cannot be automatically translated or equated to a different scale. This perspective is critical for understanding that changes to irrigation at small spatial scales may influence water users at larger scales. In addition, decisions made at a farm or canal scale to achieve a certain objective may have different, and unintended, consequences at the watershed scale.

Even when spatial scale is taken into account, describing irrigation water use in terms of high or low irrigation efficiency can lead to confusion for two reasons: (1) the term irrigation efficiency does not describe the fate of diverted water that is not consumed by crops, and (2) as the term efficiency implies savings of some kind, water conservation and irrigation efficiency are often conflated. This misconception has led to the proposal of new terminology based on fractions instead of efficiencies (Table 3). The use of fraction-based terminology can lead to greater clarity and more accurate understanding of water use. ${ }^{21}$

\footnotetext{
${ }^{k}$ For systems in which excess agricultural water largely evaporates before it can contribute to aquifer recharge or subsequent downstream water supply, increasing efficiency of
} conveyance and irrigation could lead to real water savings. 


\begin{tabular}{|c|c|c|}
\hline $\begin{array}{l}\text { TRADITIONAL } \\
\text { TERMINOLOGY }\end{array}$ & $\begin{array}{l}\text { SUGGESTED } \\
\text { TERMINOLOGY }\end{array}$ & DESCRIPTION \\
\hline $\begin{array}{l}\text { Beneficial } \\
\text { consumption* } \\
\text { (Crop irrigation } \\
\text { consumption) }\end{array}$ & $\begin{array}{l}\text { Intended } \\
\text { consumption }\end{array}$ & Water evaporated or transpired for the intended purpose, such as crop growth. \\
\hline $\begin{array}{l}\text { Non-beneficial } \\
\text { consumption }\end{array}$ & $\begin{array}{l}\text { Unintended } \\
\text { consumption }\end{array}$ & $\begin{array}{l}\text { Water evaporated or transpired for unintended purposes - for example } \\
\text { evaporation from fields or water surfaces, weeds, ditch vegetation. }\end{array}$ \\
\hline $\begin{array}{l}\text { Field (farm) loss } \\
\text { (i.e., application } \\
\text { in excess of plant } \\
\text { needs leading to } \\
\text { deep percolation and } \\
\text { surface runoff) } \\
\text { Conveyance loss } \\
\text { (i.e., evaporation, } \\
\text { seepage, plant } \\
\text { transpiration from } \\
\text { canals, faulty } \\
\text { headgates, unneeded } \\
\text { diversions) }\end{array}$ & $\begin{array}{l}\begin{array}{l}\text { Groundwater } \\
\text { recharge }\end{array} \\
\text { Irrigation runoff } \\
\text { (tailwater) } \\
\text { Unintended } \\
\text { consumption } \\
\begin{array}{l}\text { Non-recoverable } \\
\text { seepage }\end{array}\end{array}$ & $\begin{array}{l}\text { Water delivered to a field that does not contribute to intended consumption } \\
\text { and conveyance water that does not make it to the field are often considered } \\
\text { losses. This water actually has four potential fates and, from a watershed-scale } \\
\text { perspective, only the latter two result in water 'lost' or removed from the system: } \\
\text { Groundwater recharge - seeps into the underlying aquifer and becomes } \\
\text { available for reuse downstream } \\
\text { Irrigation runoff (tailwater) - flows over fields to rejoin a surface water body, or } \\
\text { flows in canals to ponds, wetlands or back to the source } \\
\text { Unintended consumption - is evaporated or transpired for purposes other than } \\
\text { the intended use } \\
\text { Non-recoverable seepage - seepage that does not make it to the aquifer or } \\
\text { back to surface water, or becomes too contaminated to be considered viable for } \\
\text { reuse downstream }\end{array}$ \\
\hline $\begin{array}{l}\text { Irrigation efficiency } \\
\text { (Total) }\end{array}$ & $\begin{array}{l}\text { Consumed } \\
\text { Fraction (CF) } \\
\text { Reusable } \\
\text { Fraction (RF) } \\
\text { Non-Reusable } \\
\text { Fraction (NR) }\end{array}$ & $\begin{array}{l}\text { Using terminology that refers directly to the fractions defining irrigation } \\
\text { efficiency and the fate of diverted irrigation water can provide an accurate and } \\
\text { value-free means to convey these concepts. } \\
\text { Consumed Fraction (CF) is synonymous with Total Irrigation Efficiency. } \\
C F=\text { Evapotranspiration (ET) } \div \text { Diversions } \\
\text { Reusable Fraction (RF) is the remainder. } \\
R F=1 \text { - Consumed Fraction OR (Diversions - ET) } \div \text { Diversions } \\
\text { For more accuracy, the Non-Reusable Fraction should also be figured into the } \\
\text { equation: } \\
C F=E T+\text { Non-Reusable Fraction (NR) } \div \text { Diversions } \\
R F=1-C F O R \text { (Diversions - ET - NR) } \div \text { Diversions } \\
\text { Conveyance Efficiency and Application Efficiency can also be calculated and } \\
\text { defined by Consumed and Reusable Fractions. }\end{array}$ \\
\hline
\end{tabular}

*This term implies consumption that benefits the user but is not defined by law, as is the term "beneficial use".

Table 3 | Terminology. The use of more precise terminology to describe irrigated agriculture systems could help promote a broader and more accurate understanding of how water moves through these systems. Some of the frequently used terms are also value-laden, which, positive or negative, can affect how accurately a term is understood. Alternative terminology that is precise and value-free is suggested above. This list represents a selection of important terminology but is not exhaustive. 


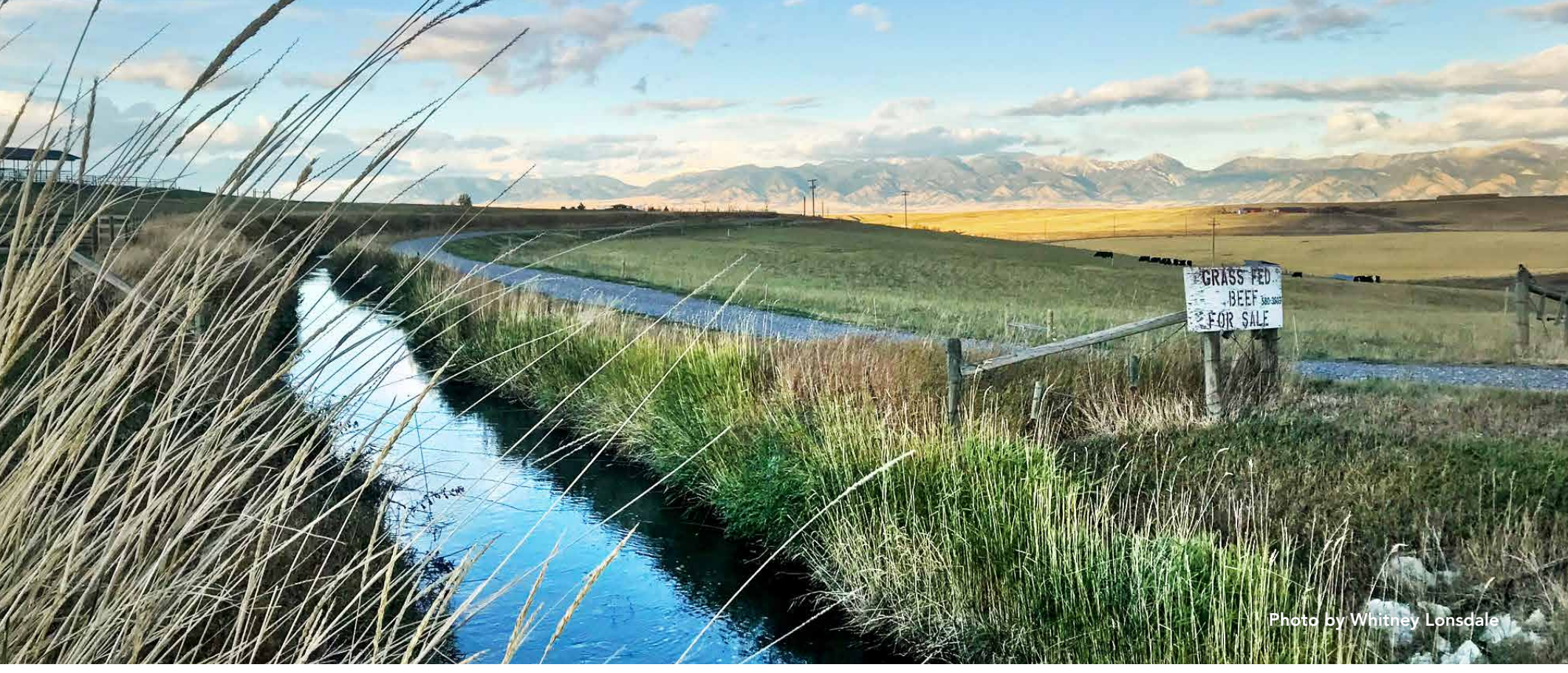

\section{Irrigation influences the spatial and temporal availability of water}

Understanding when and where water is available and needed is a critical element in water planning and balancing water supply and demand. As discussed above, changes to irrigation method or technology can alter the timing and location of water availability within a watershed. ${ }^{22}$ For instance, conversion from flood to sprinkler or lining of canals may reduce irrigation diversions, leaving more water instream at the time and place of diversion. In the spring, this may help to maintain high streamflow that is important for aquatic habitat and species that depend on flushing flows and gravel transport (Box 4). During later summer, this could help restore connectivity along a stream or between headwaters streams and mainstem rivers, which is essential to spawning and other lifecycle events of aquatic species. However, conversion to sprinkler or lining canals may also increase consumption and reduce aquifer recharge and irrigation return flows, which in turn could cause downstream reductions in late summer and early fall streamflow and reduce the stream cooling provided by groundwater return flow. Conversion may also affect the existence and distribution of wetlands ${ }^{23}$ which provide critical habitat for migratory waterfowl, ${ }^{24}$ support high diversity and abundance of other plants and animals, and also provide important services to human communities such as erosion control, enhanced water quality, and flood control.

Individual farms, fields, and sections of canal contribute varying amounts of aquifer recharge; return flow from each will affect streamflow at different locations and times of the year. For example, return flow from one farm may influence streamflow during the same irrigation season and in the same watershed. In contrast, return flow from another farm may not affect streamflow for many months or longer, or may appear far downstream in a larger watershed. Therefore, understanding the specific temporal and spatial consequences of changes in irrigation is critical, and these consequences should be considered carefully in the context of identified watershed goals.

\section{Site specificity}

The important site-specific variation and unique characteristics of individual farms and geographic regions have a large influence on the spatial and temporal implications of changes in irrigation. For instance, hydrogeologic and geographic factors such as soil characteristics, underlying geologic material, depth to the aquifer, field slope and shape, distance of a field or canal from a stream or river, and elevation/position in a watershed, all influence how water moves through the system and how groundwater and surface water interact. In addition, cropping systems, water rights' status and administration, cooperative agreements among water users, and individual decision-making influence water use and how changes in methodology will impact water availability. Therefore, while a conceptual discussion of actions and impacts is important and informative, it is difficult to generalize how changes in irrigation or conveyance method might influence water availability at different sites or watersheds. Clearly, site-specific understanding of potential impacts and outcomes, considered in relation to watershed goals and priorities, will be crucial for effective decision-making for individual water users and communities. 


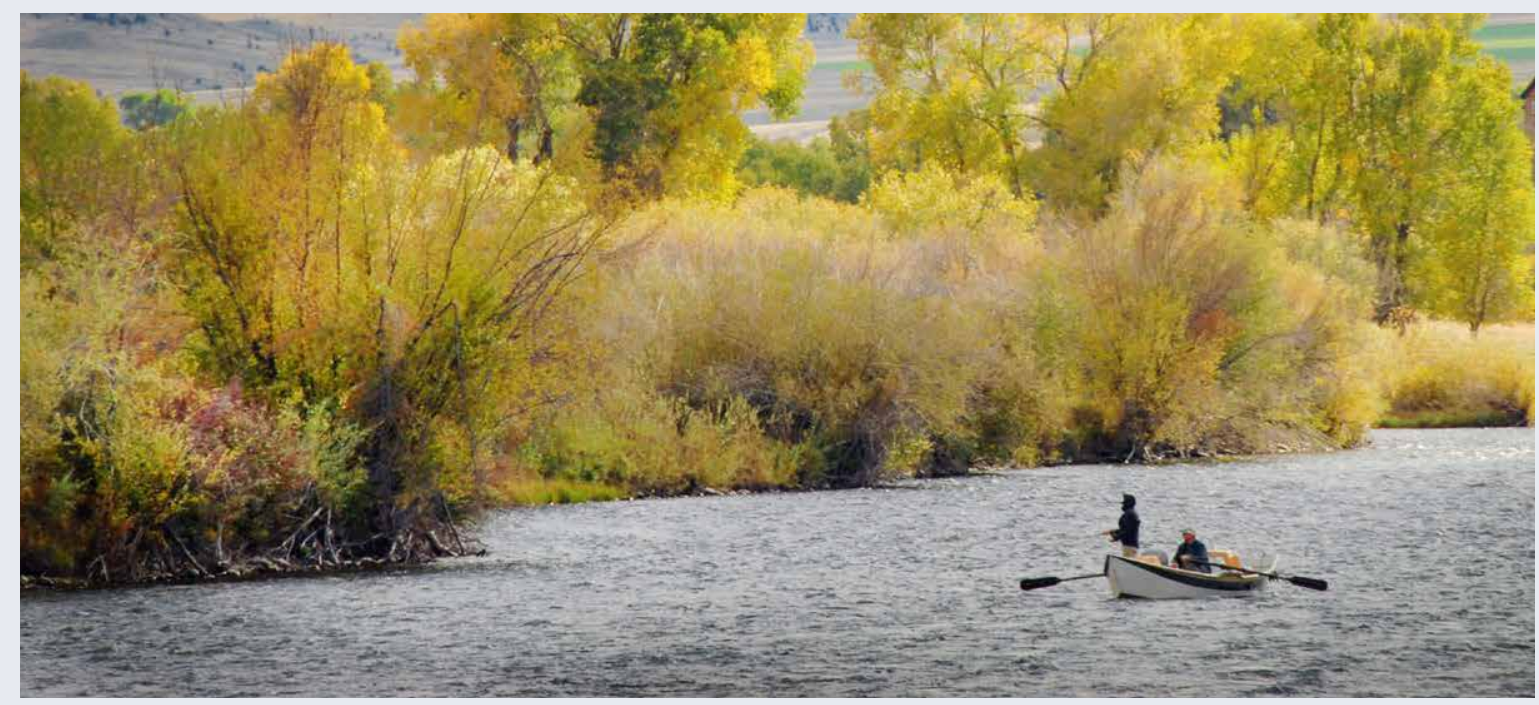

\section{BOX 4 STREAMFLOW AND AQUATIC ECOSYSTEMS}

Rivers and streams exhibit natural flow regimes that are characterized by the amount, temporal pattern, and predictability of streamflow throughout the year. ${ }^{25}$ In a large portion of western Montana, the flow regime is strongly influenced by snowmelt, with peak runoff during the spring, and low and relatively steady flows in the summer and early fall (Figure 7). ${ }^{26}$ Further east, other patterns of flow emerge, including early runoff of low-elevation snow in the plains or more erratic summer flows in response to localized rain events. Organisms that inhabit rivers, including microbes, plants, invertebrates, amphibians, and fishes have adapted to these local patterns of flow over long periods of time, and have thus evolved various behaviors, life-cycle events, or physiological processes that are directly tied to different components of the flow regime. ${ }^{27}$

For some species such as rainbow and cutthroat trout, rapidly rising spring flows and high peak flows are important because they trigger movement to spawning sites and successful spawning events. Other fish species such as bull and brown trout spawn during fall months and thus require adequate and relatively stable minimum flows during this time for movement, spawning, and the successful development of eggs. Aquatic insects, an important component of river food webs, are also influenced by patterns of flow and associated changes in river temperature and light penetration. Many of these species require specific environmental cues, such as changes in day length or rapid shifts in temperature, to complete larval development and emerge from the water as adults.

During the summer and fall, particularly low flows can influence the ecology of streams because these conditions tend to elevate both stream temperature and nutrient concentrations, both of which control species physiology and growth. Extremely low flows during drought years can lead to temperatures that exceed thermal tolerance limits for many fishes, causing recreational fishing closures (i.e., 'hoot-owl days') and mortality events. Warm temperatures and high concentrations of nutrients can also stimulate large blooms of algae and plants, and because these organisms consume oxygen at night, these blooms can produce critically low nighttime oxygen levels that can jeopardize fish and lead to permanent changes to river communities.

Flow also plays a critical role in moving and redistributing river sediments, providing the 'fuel' that shapes and reinvigorates riverbeds and floodplains over time. These processes not only influence the formation and maintenance of riparian vegetation, floodplain wetlands, and fish and bird habitat, but also sustain critical hydrologic connections between rivers and their floodplains, and between surface water and groundwater.

Irrigation practices have a clear influence on the flow regime of local rivers and streams (Figure 8), but the specific effects - and the timing of these effects - vary depending on the scale and type of irrigation and the environmental and spatial context. As we work to sustain and balance both healthy freshwater ecosystems and the livelihoods and well-being that depend on them, it is important that we explore irrigation water management options that can benefit both producers and aquatic ecosystems. 


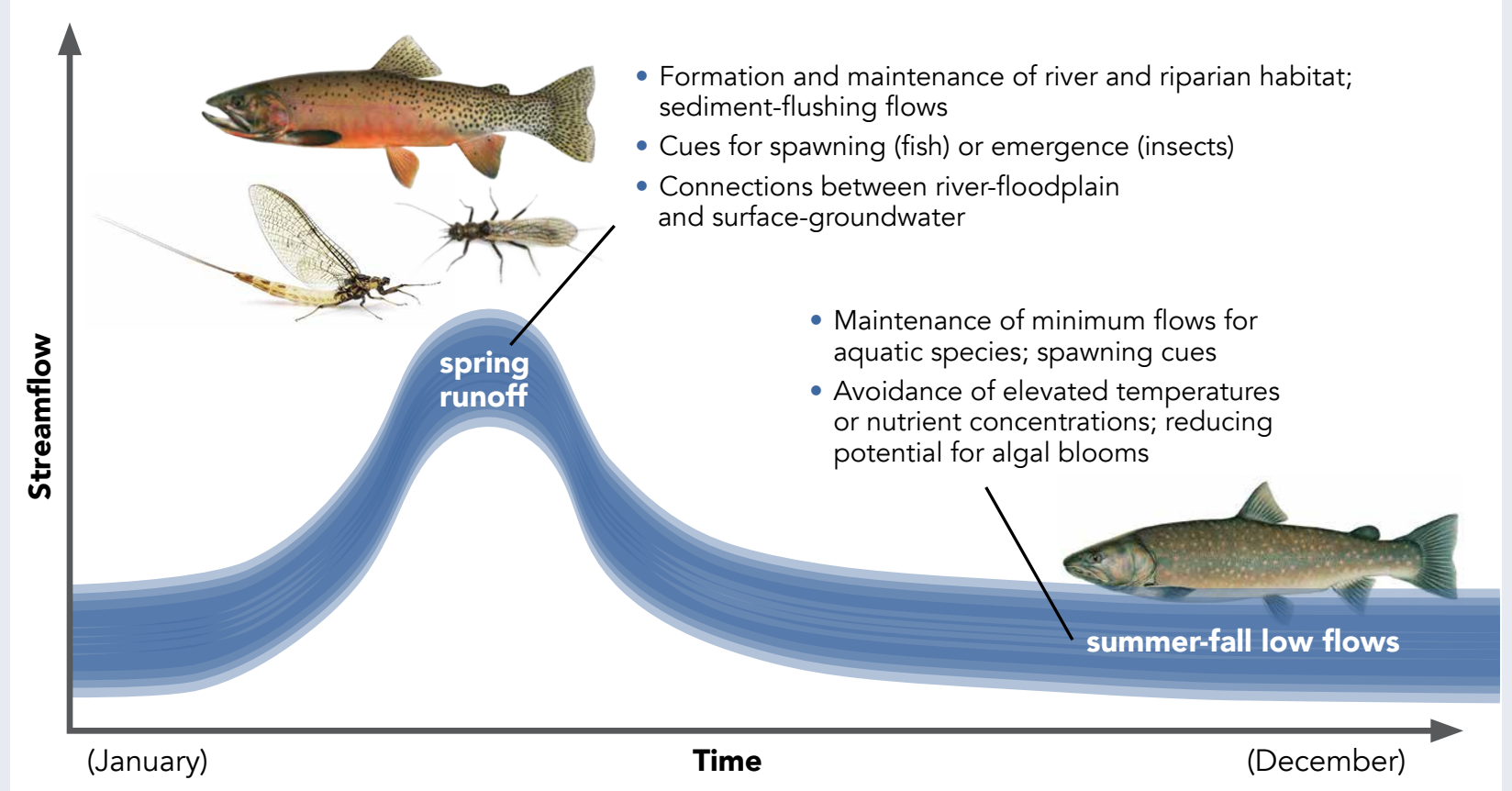

Figure 7 I Importance of flow regime to aquatic ecology. Generic flow regime of a snowmelt-dominated river in Montana. The inset boxes and photos highlight portions of the flow regime that are particularly influential for aquatic ecology.

(Fish illustrations by Joseph Tomelleri.)

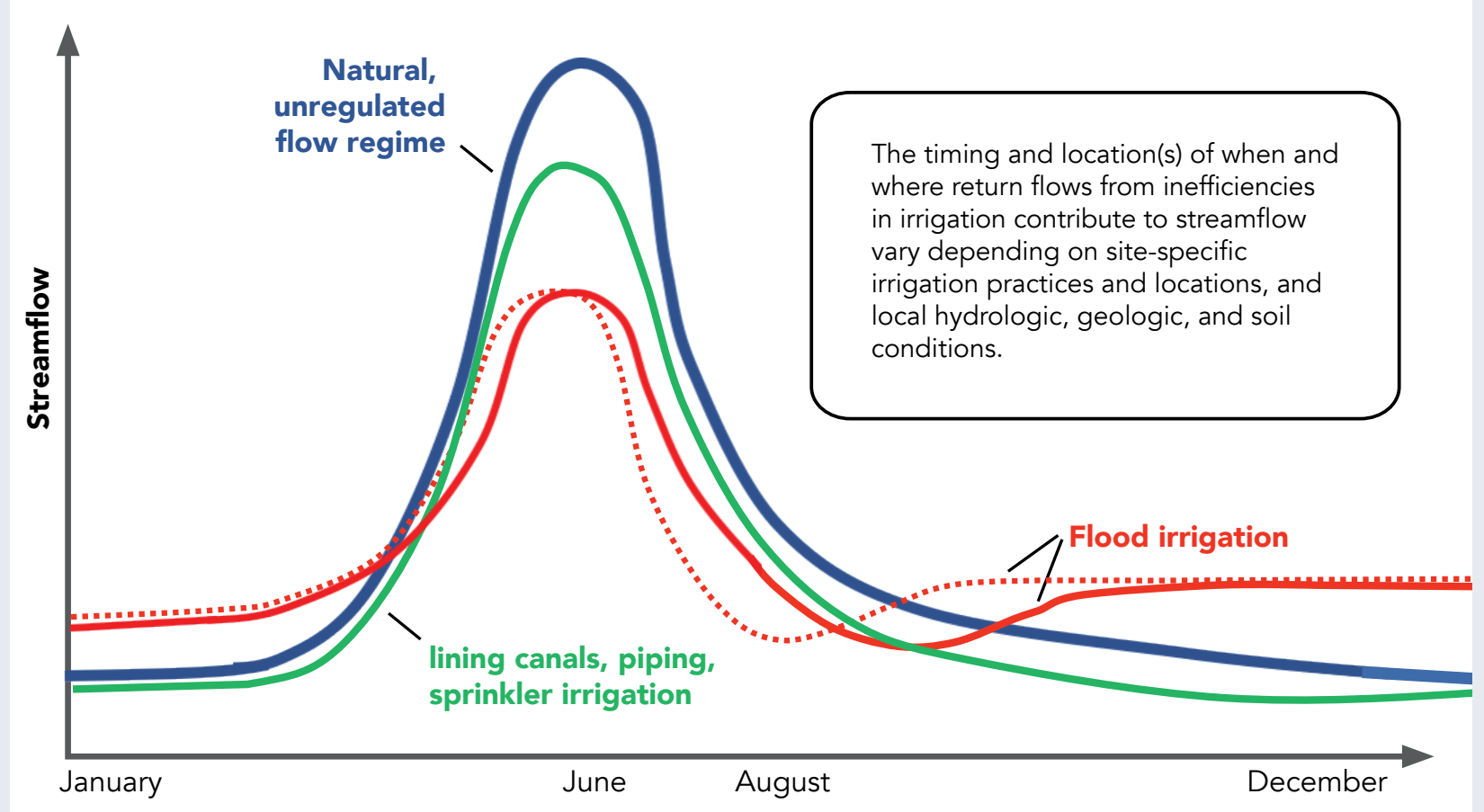

Figure 8 | Conceptual differences in flow regime as a result of irrigation management practices. Flood irrigation may reduce streamflow during the spring and summer due to large diversions. Irrigation return flow can bolster baseflow in late summer, fall, and winter, with timing varying considerably. The solid and dotted red lines represent hypothetical variation of the influence of flood irrigation return flows on seasonal streamflow. Sprinkler irrigation may have a smaller effect on maximum and minimum flow but results in less return flow contribution to baseflow. Note that this figure is generalized and does not represent the effects of irrigation at all locations. 

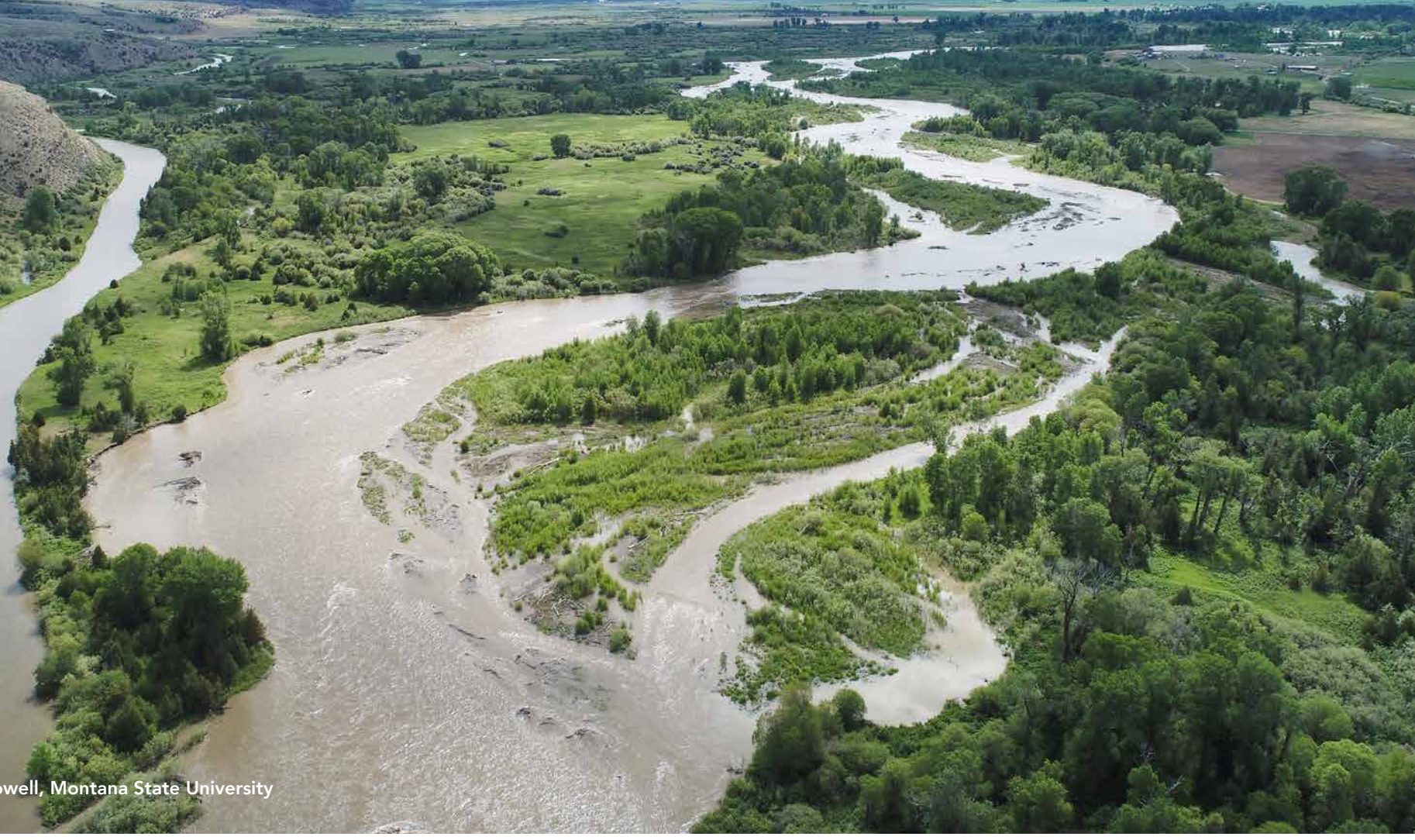

\section{WATER POLICY AND IRRIGATED AGRICULTURE}

Understanding and quantifying the hydrology, geology, and soil characteristics of a particular system is essential for informed decision-making, but it is only one piece of the complex puzzle of water and irrigation management in Montana. The body of policy around water rights and the ability to change those rights also has enormous influence on why, when, how and how much water moves through irrigated watersheds in Montana. This section provides a brief primer on water policy, examines connections between policy and changes in irrigation methodology, and highlights some of the complexities that exist at the intersection of policy, practice, and hydrology.

\section{Montana water policy basics}

The Montana Constitution was first ratified in 1889 and established that all water within state boundaries is property of the state for use by its people. Citizens cannot own water, but instead attain a right to use it. Historically, a person only needed to use water beneficially, i.e. not waste it, to establish a claim. By 1900, law required water users to also file water use claims at district courthouses. In doing so, many water users filed maximum use 
amounts, so that today the totality of filed water rights exceeds supply in most years.

Through this process of filing historic claims to water, the doctrine of Prior Appropriation was adopted in Montana. This central tenet of water law across the arid western U.S. created a system of priority (i.e., "first in time is first in right") which ensures that the oldest established water rights are fulfilled before those established at later dates. For the first three quarters of the 20th century, the use of water remained a key way of establishing claim, water rights claims remained decentralized, and information existed only within district courthouses. In 1973, the Montana Legislature passed the Montana Water Use Act (MWUA) ${ }^{28}$ requiring all water users to file their historic water use claims with the state. In addition to establishment of a central water rights database, the law created a system for issuing new (post-1973) water rights, or 'permits', through the Montana Department of Natural Resources and Conservation (DNRC), and a process for changing parts of a water right. The MWUA outlined a statewide water right adjudication process, and in 1979 the newly established Montana Water Court began examining and finalizing all pre1973 claims, a process that is still ongoing.

Water rights (pre-1973 claims and post-1973 permits, collectively) describe when, where, why, how much, and for how long water can be used. Components of a water right include priority date, water source, point of diversion, purpose of use (also called beneficial use'), place of use, flow rate and volume, period of use, and period of diversion. ${ }^{29,30}$ Water users can apply to DNRC to change up to four elements of their water right: the point of diversion, place of use, purpose of use, or place of storage; ${ }^{31}$ no other elements of a water right can be changed. Montana case law has established that water rights are measured by, and limited to, the amount of water historically put to beneficial use, ${ }^{32}$ and that a change cannot increase consumptive use. Therefore, during the water right change process, the DNRC conducts a historic use analysis to determine the amount of water historically put to beneficial use. The historic consumptive use calculation is not equivalent to the flow rate, volume, and diversionary amount that appear on a water right abstract. This is a common source of confusion for water right holders because most do not know their exact historic consumptive water use unless they have been through the change process.

\section{Water policy and changes in irrigation method}

Although the relationships between water policy and changes in irrigation method are complex, the policy is relatively straightforward: an individual's ability to freely change irrigation method without government approval is protected under law. In fact, Montana law specifically excludes a change in method of irrigation from the definition of a "change in appropriation right" requiring DNRC approval: "A change in appropriation (water) right . . does not include a change in water use related to the method of irrigation. " 31 This enables water users to change their method of irrigation without securing DNRC approval, even though the conversion from flood to sprinkler irrigation has the potential to increase consumptive use beyond historic quantities.

Consider an irrigator who converted from flood to center pivot irrigation at some point after 1973. Her water right is predicated on the amount she consumed historically (pre-1973) to flood irrigate. This irrigator may knowingly or unknowingly increase her consumptive use when she converts to pivot irrigation because of higher crop yields or changes to more water-consumptive crops. If this irrigator then applies to change an element of her water right, DNRC is required to examine present water use compared to historic consumptive use and may document an increase in use. This situation has caused concern about the change process, potentially impeding actions or strategies that require changes to water rights, such as leasing instream flows.

The conversion from flood to sprinkler irrigation also has the potential to reduce return flows, despite the fact that Montana policy specifically prevents water users from adversely impacting other water right holders, including disrupting the amount and timing of return flows on which other downstream water users may rely. There is currently no legal mechanism for preemptively regulating both the increase in water consumption and the impacts to return flows that may result from changes in irrigation methods (Case Study 1). As discussed above, this may lead to unintended consequences for watersheds and downstream users in terms of seasonal water supply and availability.

\footnotetext{
$l^{l}$ In Montana, beneficial use is defined as a use of water for the benefit of the appropriator, others persons, or the public, including but not limited to agriculture, stock water, domestic, fish and wildlife, industrial, irrigation, mining, municipal, power, recreation, water leasing, instream flow, aquifer recharge for mitigation, and aquifer storage and recovery.
} 


\section{CASE STUDY 1: U.S. Supreme Court decision for the Tongue River Basin (Montana v. Wyoming) (3-36 $^{3-36}$}

Does conversion from flood to sprinkler irrigation lead to conservation of water? An excellent example of the confusion surrounding this issue is illustrated by the outcome of Montana's litigation with Wyoming over violations of the Yellowstone River Compact. Water shortages in the Tongue and Powder River sub-basins during the drought of 2000 to 2006 motivated Montana to litigate four claims of damages before the U.S. Supreme Court. One claim was that Wyoming's conversion from flood to sprinkler irrigation in the Tongue River basin had increased water consumption to the detriment of downstream Montana water users. Montana's brief alleged that Wyoming's conversion to sprinklers in the Tongue River Basin increased water consumption from $65 \%$ of water diverted to $90 \%$; as a result, return flows were reduced from $35 \%$ of diverted water to only $10 \%$, and this had harmed downstream Montana water users. The Special Master ${ }^{m}$ found that these improvements, although resulting in increased Wyoming consumption, were permissible under the Compact, and the Court ultimately endorsed this conclusion.

The Master sought to answer the following question:

\section{[C]an an agricultural appropriator, increase his or her consumption of water, on the same irrigated acreage to which the appropriative right attaches, to the detriment of downstream}

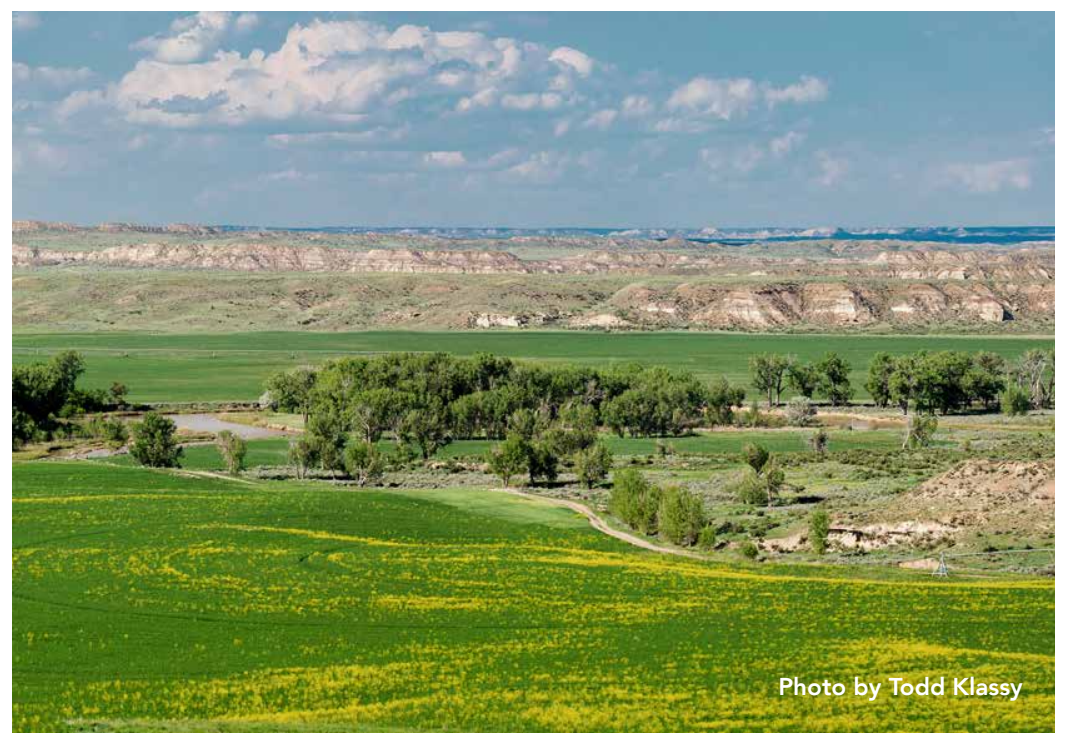

\section{appropriators, in the same water system from which the water was originally withdrawn?}

The Master performed an exhaustive review of western case law regarding the doctrines of prior appropriation and recapture of water, and concluded:

"Given the law of prior appropriation both at the time the Compact was negotiated and today, I conclude that the Compact does not prohibit Wyoming from allowing pre-1950 appropriators in the State to increase their consumption of water on the lands they were irrigating as of January 1, 1950 by improving their irrigation systems, even when that reduces the runoff that reaches Montana".

Montana filed numerous exceptions to this finding based on Compact interpretation. Montana held that it was guaranteed a certain amount of water crossing the state line to satisfy its needs at the time of Compact ratification in 1950, and that Wyoming's conversion to sprinklers reduced that volume and violated that guarantee. The Court upheld the Master's conclusion with a vote of seven to one, with Justice Scalia dissenting.

Ironically, the Master also supported his conclusion stating that it furthers the important policy objective of improving water conservation. However, at the larger watershed scale view, where increased consumption may reduce downstream streamflow, alter the historic pattern of return flow, and affect other water uses dependent on that pattern, it is problematic to claim that this amounts to conservation - or the use and consumption of less - water.

$m$ The U.S. Supreme Court appoints a Special Master to oversee the litigation (discovery, briefs, and evidentiary hearings) and make recommendations to the Court. 


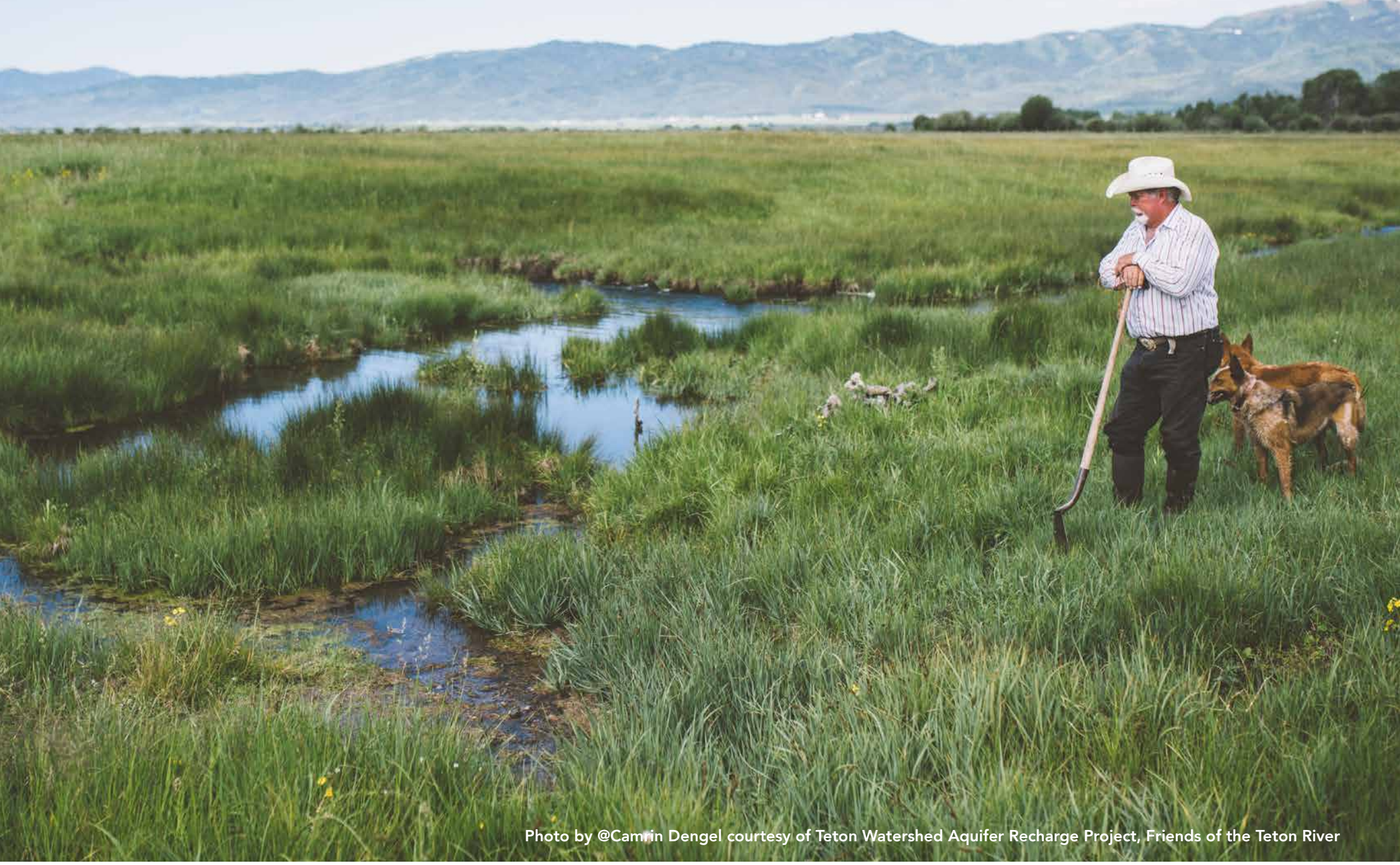

\section{ADAPTING TO CHANGE}

The continued vibrancy of agriculture is essential for food supply and for Montana's economy, rural livelihoods, and cultural and natural heritage. As the state supports the agricultural sector in building the capacity to tackle present and future challenges, agriculture can, in turn, play an important role in planning for and meeting Montana's future water demands.
Because shifts in irrigated agriculture are coinciding with changes in climate and development (Box 5), it is critical to consider how to maintain or improve the resilience of Montana's communities and natural resources. This section builds from our working group meetings to examine various actions that could support irrigated agriculture and contribute to robust watersheds and communities. We discuss three general goals, as well as multiple strategies for achieving these goals. We also highlight constraints that might limit innovation, as well as opportunities for management and policy. Our intention is to provide information that can complement local knowledge and experience in ongoing efforts to meet specific goals and objectives at the farm or watershed level. 


\section{BOX 5 MONTANA'S CHANGING CLIMATE}

\section{OBSERVED CHANGES}

- Since 1950, average annual temperatures have increased by $2.7^{\circ} \mathrm{F}$, a full degree more than the national average.

- April 1 snowpack has declined 20\% since the 1930s, with the greatest declines at low elevations.

- Peak spring runoff is arriving one to three weeks earlier, on average, in the Mountain West.

\section{PROJECTED CHANGES}

- Warming will continue and is likely to be more pronounced in the summer.

- Days above $90^{\circ} \mathrm{F}$ are projected to increase by 10 to 35 days per year by 2050

- Flood events and multi-year droughts will continue to be a part of Montana's climate, as they have been in the past, with a strong potential for increased frequency and/or intensity of these events.

- Changes in temperature, snowpack, and precipitation are likely to increase the frequency and severity of droughts during the summer months.

- Total annual precipitation in Montana is likely to increase slightly, but precipitation is projected to decrease during the summer months when demand is highest.

\section{POTENTIAL EFFECTS ON IRRIGATED AGRICULTURE}

- Reductions in snowpack, altered runoff patterns, and lower summer streamflow are likely to affect the capacity and reliability of irrigation water supply.

- Warming may extend the growing season and enable greater crop diversity, but increasing summer heat and drought will lead to greater water demand and potential stress on crops and livestock.

- Higher winter temperatures may allow winter annual weeds, such as cheatgrass, to increase in distribution and frequency across winter wheat cropland and rangeland.

\section{The impacts on water supply from these climatic changes will be exacerbated by population growth and development pressure.}




\section{Goal 1: Watershed-scale Irrigation Management and Water Budgeting}

Irrigated agriculture has a profound influence on watershed hydrology; consequently, irrigation water management can function, where desired, as a tool to help communities achieve locally identified water objectives. Effective planning to employ adaptation strategies and meet targeted watershed goals must begin with quality information, comprised of quantitative hydrologic data on water supply and use, as well as sitespecific local knowledge of how water moves through the watershed. Gathering this information and building basic water budgets can help watersheds and irrigation districts plan more effectively to meet their identified objectives, as well as build model scenarios and plan for future challenges. A number of irrigation water management strategies are currently being employed around the state, creating a foundation to be built upon and expanded.

\section{STRATEGY 1A: Development of quantitative water budgets}

A quantitative water budget accounts for all of the inputs, storage, and outputs from a particular system, such as a watershed, an irrigation district, or an individual farm. As with any budget, its reliability and utility depend on the accuracy and availability of the information used to create it. In Montana, the quality and accessibility of water data varies greatly (Constraint 1A and Table 4) and, while water measurement is taking place in some managed basins, a lack of direct measurement in many areas of the state limits informed decision-making.

Accurate site-specific information, such as the data necessary to build a comprehensive water budget or an understanding of how policy influences seasonal water availability, can provide a powerful toolbox for considering actions and building solutions that fit particular watershed goals. ${ }^{37}$ In Idaho, for example, headgates with measurement devices track diversion rates in all watersheds, and the state is systematically investing in detailed hydrologic models to support agriculture, communities, and ecosystems. With realtime data and accurate measurements feeding these models, Idaho can explore how changes in climate, irrigation methodology, and land use might influence water supply. They can also use these models to consider actions and priorities, and to plan proactively to mitigate potentially adverse outcomes.

\section{STRATEGY 1B: Voluntary drought management plans}

Water users in many areas of Montana have come together to create voluntary drought response plans to minimize the adverse impacts of drought and low flow events. The Blackfoot Drought Response Plan ${ }^{38}$ is one such effort, which demonstrates the idea of "shared sacrifice" among all water users (i.e., irrigators, outfitters, anglers, recreational users, government agencies, homeowners associations, businesses, conservation groups, and others) who "voluntarily agree to take actions that will result in water savings or the reduction of stress to fisheries resources during critical low flow periods." This approach recognizes that drought and low flows are a watershed-wide concern, that individuals and entities throughout the watershed benefit from drought response efforts, and that the greatest benefit can only be achieved by the cooperative effort of the broader community. Within the broader Blackfoot Drought Response Plan, individual water users have developed drought management plans specific to their own needs and conditions. Voluntary drought response plans exist in other watersheds across the state, such as the Big Hole $^{39}$ and the Jefferson ${ }^{40}$ and represent an important water management tool that can promote community and drought resilience.

\section{STRATEGY 1C: Flexibility in water management through irrigation districts}

Irrigation districts provide unique opportunities for irrigation water management due to their scale, structure, and water rights configuration. Irrigation districts are quasi-governmental entities that are formed to manage the distribution and delivery of contract water. Each district contracts water delivery shares to producers within the boundaries of the district. The shares can be sold or transferred among different irrigators without requiring a change of water right, since the place and period of use do not change; this situation creates unique flexibility in terms of moving water within the system and optimizing water use in relation to demand or potential aquifer recharge efforts. Many of the districts are associated with large diversion or reservoir projects which provide water to thousands of irrigated acres using many miles of canals and ditches. The large geographic footprint of some irrigation districts can create challenges for management, but can also represent significant potential to influence the hydrology of the area. 


\section{Constraints and Opportunities Related to Irrigation Management and Water Budgeting (Goal 1)}

\section{CONSTRAINT 1A: Limited water supply and use information}

There are significant gaps in the information necessary to construct reliable water budgets to inform

planning (Table 4). For example, actual diversion rates throughout the season are not accessible for much of the state, empirical data on field application rates is broadly lacking, and accurate measurements of the effects of irrigation return flow on streamflow only exist where specific studies have taken place. Only recently have methods been developed to use remote sensing to estimate evapotranspiration. ${ }^{41-43} \mathrm{It}$ is also important to build knowledge about other factors that influence water availability and how they interact with hydrology. For example, it is essential to understand how policy enables or constrains particular strategies, as well as the socio-cultural and economic factors that drive decision-making within a particular watershed.

\section{CONSTRAINT 1B: Funding for data collection and analysis}

Data collection, management, and analysis require significant financial investment. Automated forms of data collection may require considerable initial funding but less to maintain in the long-term, while other forms of data collection may require steady, ongoing resources. To be useful, all data must be managed in a way that makes it accessible, and data cannot inform decision-making without analysis to interpret what it means. Resources for education and outreach efforts are also critical for creating pathways of information exchange among researchers, policy makers, and practitioners.

Table 4 summarizes gaps in data for key elements of the water budget, as well as other information needs that could contribute to better understanding and informed planning around irrigation efficiency.

\section{CONSTRAINT 1C: Water right abandonment policy}

The water right abandonment tenet, ${ }^{44}$ commonly referred to as "use it or lose it," is widely perceived as a requirement that water right holders use their full water right each year or run the risk of losing it. However, while the tenet holds that use of the water right is important, it does not explicitly require a water right to be used in full every year; abandonment occurs when a water user stops using all or part of a water right for a period of 10 successive years. Interestingly, the water right abandonment tenet currently exists solely as a guideline and will become enforceable statute once the final decree of water rights in Montana is complete. Nonetheless, whether the risk is real or perceived, the fear of abandonment remains widespread. As such, it serves as a strong disincentive for water rights holders to adjust use according to need or scarcity, and has become a specter that looms over many well-intentioned water conservation efforts.

House Bill 54 in the 2017 legislative session sought to amend the water right abandonment tenet to allow water users to cease all or part of use of a water right during a drought and in compliance with a local, regional, or state drought plan. The bill failed; however, if water rights holders could reduce their water use during times of water scarcity without fear of abandonment, or even to meet community watershed goals, more possibilities would exist for adaptive, creative solutions for water management.

\section{CONSTRAINT 1D: Development and fragmentation of agricultural land}

Watershed-scale irrigation management and many of the strategies outlined in this document necessitate collaboration and collective action among water rights holders, landowners, and other community members. Voluntary drought management, for example, is only effective if the vast majority of water users participates, and the use of irrigation canals to promote aquifer recharge requires agreement and cooperation among multiple water users within a ditch network or canal system. Increasingly, especially in the western half of the state, watershed-scale irrigation management has to take into account changes in land use and the growing fragmentation of agricultural lands due to development and population growth. When a farm or ranch is sold and the land is subdivided, the water right is also divided among the multiple new landowners. In these cases, collective action to achieve a particular objective using irrigation infrastructure may become more difficult because of the multiple interests among new landowners and an increasingly diverse set of water use goals. In the face of these changes, local watershed groups become increasingly important in their ability to build trust, foster understanding of the local context, and cultivate site-specific solutions to match watershed needs. Additionally, efforts to better integrate water use planning into land use planning will enable watersheds and communities to address potential challenges in a more proactive manner. 


\section{KNOWLEDGE GAPS}

\section{TOPIC/WATER BUDGET COMPONENT \\ KNOWLEDGE GAPS}

\begin{tabular}{|c|c|}
\hline Surface Water Supply & $\begin{array}{l}\text { - Continued and expanded surface water monitoring in Montana at strategic locations } \\
\text { - State-of-the-art modeling efforts to predict how changes to the environment or } \\
\text { management practices might influence water supply } \\
\text { - More nuanced/detailed and site-specific understanding of GW influence on surface } \\
\text { water supply }\end{array}$ \\
\hline Aquifer Recharge & $\begin{array}{l}\text { - Realistic estimates of irrigation return flow effects on streamflow } \\
\text { - Quantifying irrigation-related recharge as a component of the larger water budget }\end{array}$ \\
\hline ET/Crop consumption & - High resolution remote sensing to provide accurate estimates of evapotranspiration \\
\hline Diversions & $\begin{array}{l}\text { - Update maps of ditch location/extent } \\
\text { - Simple and reliable automated instrumentation for diversion measurement and } \\
\text { reporting }\end{array}$ \\
\hline Field Application & - Empirical data on actual irrigation water application rates/quantities \\
\hline Water Budget Data Compilations & $\begin{array}{l}\text { - Update past efforts such as Water Resource Surveys and } 1978 \text { NRCS Water } \\
\text { Conservation Salvage Report }\end{array}$ \\
\hline Montana Irrigation and Conversion Rates & $\begin{array}{l}\text { - Reliably mapped irrigated lands, including spatial extent, crop type, irrigated acres } \\
\text { - Quantification and assessment of lined and unlined canals }\end{array}$ \\
\hline Information Transfer \& Education & $\begin{array}{l}\text { - Knowledge transfer among irrigators, policy makers, scientists, agencies, with } \\
\text { information flowing in all directions } \\
\text { - Clarity in nomenclature and terminology } \\
\text { - Promoting understanding of hydrology around irrigated agriculture to a broader } \\
\text { audience }\end{array}$ \\
\hline
\end{tabular}

Table 4 | Knowledge Gaps. Key knowledge gaps related to specific water budget components and our general understanding of the hydrology of irrigated agriculture.

\section{Goal 2: Supporting Aquifer Recharge}

In many watersheds across Montana, water is stored naturally in winter snowpack and large alluvial aquifers. Water users depend on these forms of natural storage to provide sufficient water for irrigation and adequate streamflow, especially during the late summer and fall. The conversion from flood to sprinkler irrigation is likely to reduce aquifer storage over time through reduced irrigation seepage. In addition, climate warming continues to deplete winter snowpack. It is therefore important to consider other means of slowing down plentiful spring flows and storing water for use later in the year or farther downstream. Given the extremely high monetary and environmental costs of building dams and reservoirs, and the significant evaporative loss from existing reservoirs, ${ }^{1}$ managing or manipulating aquifer recharge could provide a solution for increasing storage and resilience to drought. Such recharge can support wetlands, maintain aquifer levels and domestic groundwater wells, and sustain groundwater contributions to streamflow. In addition to bolstering streamflow, return flow can provide a cooling effect on streams, which can be particularly important during late summer and early fall when water temperatures can approach dangerous thresholds for certain aquatic species. ${ }^{45}$ Agricultural infrastructure may offer an underappreciated means for aquifer recharge, even as conversions to sprinkler irrigation continue.

\section{STRATEGY 2A: Maintain unlined canal infrastructure}

Unlined irrigation ditches are a significant source of aquifer recharge in many irrigated watersheds (Case Study 2). ${ }^{46,47}$ As producers convert to sprinkler irrigation and recharge from flood irrigation is reduced, unlined canals will continue to provide substantial aquifer recharge. Additionally, with an improved understanding of how, where, and when canal seepage influences streamflow, canal seepage could be managed to achieve more targeted watershed goals, such as bolstering streamflow during times or at places of low supply and high demand. These gains would need to be weighed against any potential benefits of lining canals such as leaving more water instream at the time of diversion, reducing water consumption from canal vegetation, and lessening erosion along canal networks. 


\section{CASE STUDY 2: Aquifer recharge through use of irrigation canals in the Beaverhead (MT) and Teton (ID) watersheds}

One strategy for recharging alluvial aquifers and bolstering late-season streamflow involves running water through unlined irrigation canals before and/or after the irrigation season. This concept is currently being explored through hydrologic modeling studies as well as on-the-ground efforts. Here we present a study of the Beaverhead River and its associated irrigation canal network by the Montana Bureau of Mines and Geology (MBMG) ${ }^{47}$ as well as a collaborative project by the Teton Water Users Association, a watershed group from the Teton River, Idaho. ${ }^{48}$

\section{BEAVERHEAD RIVER, MONTANA}

The Beaverhead River, flowing between Clark Canyon Reservoir and Twin Bridges, is one of two major tributaries that form the Jefferson River. Surface water irrigation dominates in this area, with most water distributed via two major canals that flow along elevated floodplain 'benches': the West Bench Canal and the East Bench Canal. In 2010, MBMG initiated a study to assess a variety of interactions between irrigation management and hydrology. As part of this effort, quantitative models were developed to explore the influence of running 'extra' water in the canals before and after the irrigation season to recharge floodplain aquifers and help offset depletions from irrigation well pumping. In addition, these models were applied to assess the contribution of irrigation return flow to the Beaverhead and how augmented canal seepage might influence this contribution. MBMG investigators determined that $\sim 20 \%$ of the annual streamflow in the Beaverhead River derives from canal seepage reentering the river as return flow. The models showed that extending the period of canal flow (i.e., one month prior to and following the irrigation season) effectively offset the groundwater drawdown and reductions in streamflow resulting from irrigation wells. In addition, the extended period of canal flow increased average annual baseflow in the Beaverhead by 5\%, even when current pumping rates were maintained (after 20 years of simulated changes). Spatial and temporal aspects of baseflow augmentation were not explored within the scope of the study.

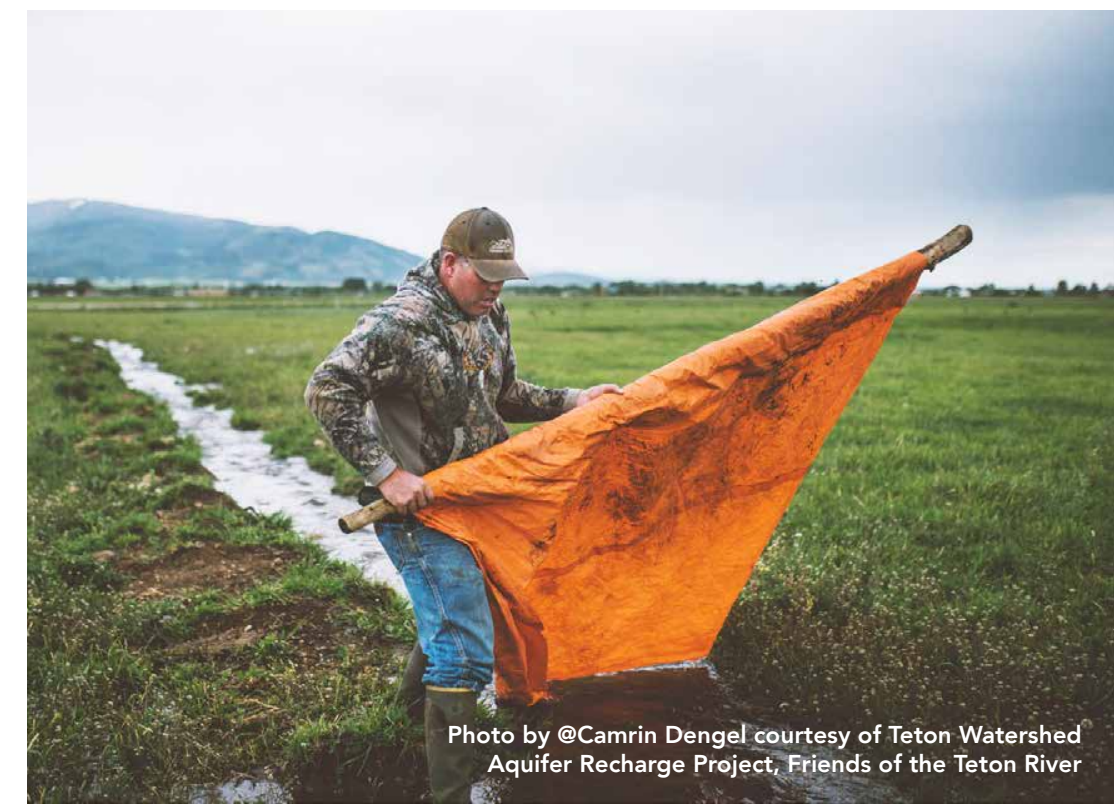

Insightful studies, such as this one, are becoming more common and results are helping to provide critical information needed to develop creative, 'win-win' solutions. An interesting, real-world example of such a solution comes from the Teton River in Idaho where resurrected flood irrigation canal systems are being used to recharge aquifers and bolster late season streamflow.

\section{TETON RIVER, IDAHO}

Idaho's Teton River flows along the west side of the Teton Mountains, originating near Victor and flowing into the Henry's Fork of the Snake River near Rexburg. Water supply for irrigation and municipal use in the Teton Valley is snowmelt-dependent, with runoff from the high elevation Teton Range leading to peak spring flows in late May/early June followed by a low baseflow period in August and September. Producers in the Teton primarily grow hay and malt barley and raise beef cattle. The majority of the water rights in the headwaters are junior and calls on these rights are made by downstream senior water users in most years. The majority of producers in the Teton have switched from flood to sprinkler irrigation over the last 40 years; this conversion has enabled them to irrigate longer into the season given their junior status, produce two hay crops per year instead of one, and improve barley yields and malt quality. However, over the past 20-30 years, producers have noticed changes in the way water flows through their valley: springs they had relied upon dry up earlier in the year, or disappear entirely, and wetlands have diminished significantly in size. At the same time, Friends of the Teton River (FTR) and the Henrys Fork Foundation (HFF), two local non-profit groups, had been collecting data that showed (-continued) 


\section{CASE STUDY 2 continued}

declining summer streamflow, rising stream temperatures, and significant declines in aquifer levels - data that coincided with the observations of the producers. While tensions had formerly existed between FTR and valley irrigators, there was increasing recognition of the damaging impacts of declining summer streamflow for agricultural livelihoods and the local fishery alike. This shared concern over a shared resource led to the formation of the Teton Water Users Association (TWUA) and collective brainstorming on how to restore aquifer levels and bolster late season streamflow.

Members of the TWUA acknowledged the value of flood irrigation methods for slowing down and spreading out plentiful spring runoff water and storing it in the watershed for later use. Yet they also knew the importance of sprinklers for later season irrigation when water is typically scarce. The formerly used, unlined canal network, largely still in existence, provided the ideal strategy to allow for early season aquifer recharge while maintaining sprinkler irrigation.

Using grant dollars, the TWUA funded the necessary repairs to the defunct canal system to begin an innovative and collaborative aquifer recharge program in 2018; the program is now in its third year. Once the ground thaws and before downstream rights come into priority, spring runoff water is diverted from the Teton using existing water rights and providing what is referred to as "incidental aquifer recharge." In a return to flood irrigation-like canal management, water is diverted as soon as it is legally available and spread through a reactivated canal system. Producers and canal companies recognize the value of the program, but their participation is also made possible and incentivized by grant dollars that are relative to the recharge they provide. The program is also piloting "managed aquifer recharge," in which a temporary water right is obtained to bring water to a particular location for focused aquifer recharge. These additional water rights are purchased with program funds. Both types of recharge are allowed under Idaho water policy and encouraged by the state, as there is widespread recognition of the value of aquifer recharge as a means of storing water and building resilience.

There is also recognition beyond the Teton Valley in terms of the value of aquifer recharge and natural water storage for increasing late season streamflow, particularly from downstream producers. While initial funds for the first five-year pilot program have been obtained from outside grants, there is considerable potential for a long-term water market, in which downstream users (producers, municipalities, etc.) would pay for aquifer recharge in the headwaters, to increase reliability of late season water supply.

The Teton River watershed has much in common with many headwaters watersheds in Montana and, although water policy differs between the two states, the general strategy is applicable and could provide similar benefits, depending on site-specific factors.

\section{STRATEGY 2B: Pre- and post-season diversion through unlined canals}

To achieve additional aquifer recharge, water could be run through an unlined canal system prior to or following the irrigation season. In many places irrigators and irrigation districts already run water through canals prior to the irrigation season in the practice of "priming" or "wetting" irrigation ditches to fill the soil profile below canals. This practice takes place within the defined periods of use; however, because climate warming is causing earlier spring snowmelt and runoff, a considerable amount of water may flow downstream and out of the watershed before irrigators are legally allowed to use it. The ability to divert a portion of this spring flow through unlined canal systems could provide additional aquifer recharge and a means of keeping water within the watershed for later use (Case Study 2). Again, site-specific spatial and temporal information on return flows from canals will allow decision makers to target specific water supply goals. Watershed-level assessment can identify and weigh the tradeoffs between leaving water instream early in the season or diverting it to increase recharge, as well as consider policy-related and physical constraints to enacting this strategy.

\section{STRATEGY 2C: Infiltration galleries}

Early runoff could also be captured for the purpose of aquifer recharge through intentionally placed infiltration galleries. Infiltration galleries generally consist of permeable gravels or engineered conduits that expedite the transfer of water to an aquifer. In this strategy, irrigation canals could be used prior to the irrigation season to deliver water to designated galleries to allow aquifer recharge. Use of infiltration galleries could mimic the application of water to farm fields prior to the irrigation season (i.e., promoting aquifer recharge and storing early runoff), but would avoid the potential risks of damage to agricultural land and water quality impairment via nutrient leaching. If managers plan to use these measures to meet specific goals, such as bolstering lateseason streamflow or influencing late-season stream temperature in a particular location, detailed local information about surface-groundwater interactions would be essential for deciding where to place engineered infiltration galleries. As in the above strategies, consideration must be given to the sitespecific tradeoffs between leaving water instream or diverting it for aquifer recharge. 


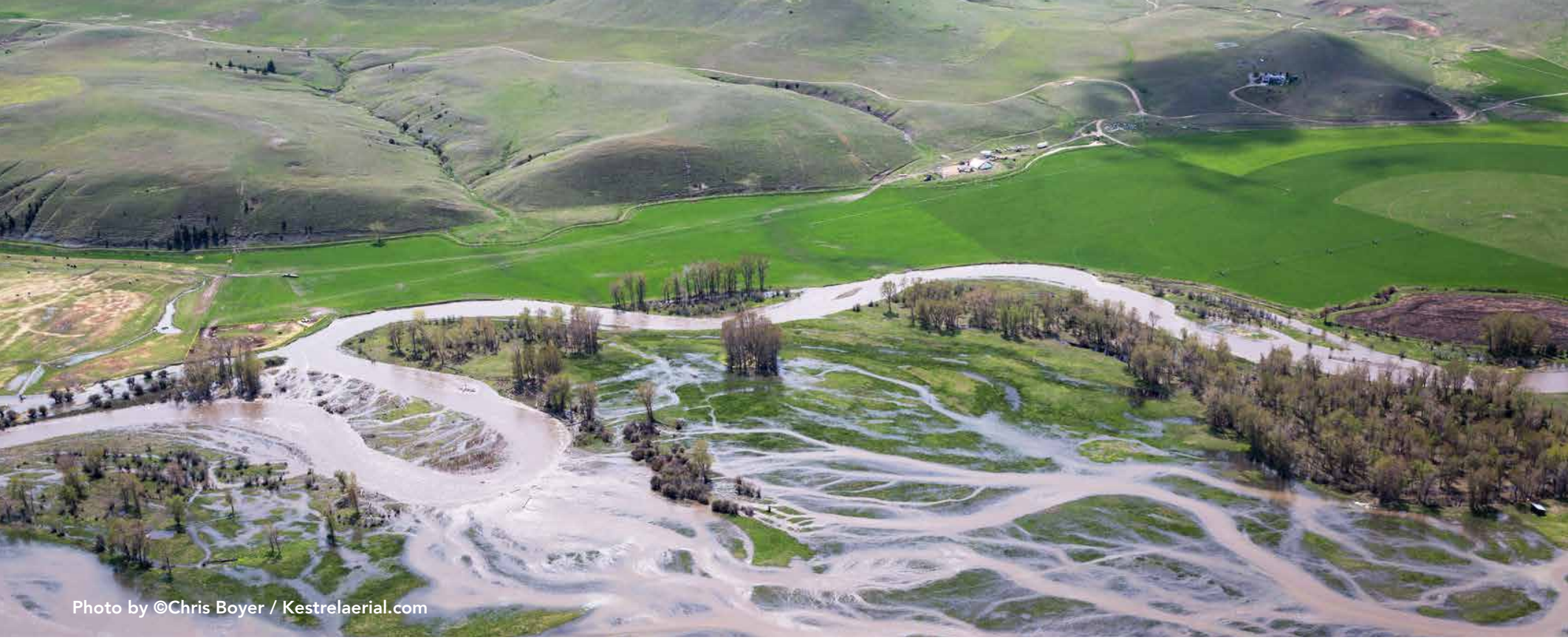

\section{STRATEGY 2D: Floodplain reconnection}

By slowing and spreading flood water, floodplains provide the opportunity for aquifer recharge, as well as exchange between groundwater and surface water that can help to keep stream temperatures cool (also see Box 4). Floodplains also support wildlife habitat, help to maintain water quality, and can reduce flood stage. Across the U.S., flood control efforts have disconnected floodplains from waterways on a large scale, eliminating their natural functions. Managing and restoring floodplains in agricultural lands adjacent to rivers can increase aquifer recharge and help to mitigate flood risk. As an example, on the Yellowstone River, channel migration easements - a specific type of conservation easement - enable landowners to use their land while also allowing natural channel migration and flooding. The program compensates landowners for land that is lost to erosion or flood damage in lieu of bank armoring or other developments that limit river and floodplain function. ${ }^{49}$ Other tools for enabling natural floodplain function include limiting floodplain development through land use planning, protecting or restoring riparian buffers, managing livestock grazing to promote healthy riparian vegetation, and managing woody invasive species such as tamarisk and Russian olive that compete with native species of willow and cottonwood.

\section{STRATEGY 2E: Hybrid irrigation management}

Hybrid irrigation management refers to the use of multiple irrigation methods across a farm or group of farms, or changes in method over time throughout the irrigation season. Some producers may already use hybrid irrigation management because the geologic or physical characteristics of their land necessitate the creative use of different approaches in different locations. Producers may also choose to voluntarily experiment with hybrid irrigation management in order to maximize the benefits of different methods or to optimize water use relative to seasonal availability. For instance, when water is plentiful in the spring and early summer, irrigators could use high-capacity sprinklers to apply excess water, or flood irrigate where possible, effectively supporting aquifer recharge. Later in the growing season when water becomes more limited, irrigators could return to standard sprinkler irrigation to optimize the balance between water supply and use. There are clearly operational constraints to employing this type of hybrid irrigation management, and these could limit the broad scale application of this strategy (Constraint 2A below); yet, for certain farms and producers this could be a feasible option. Methods and management practices could be combined to support particular water supply goals or ecological needs (Table 2), which will likely vary from one location to another.

Hybrid irrigation management could also be envisioned at a watershed scale, where diverse methods are proactively planned or maintained across large spatial scales to achieve desired watershed goals, such as maintaining summer streamflow (Case Study 3). As illustrated in Table 2 there are a variety of costs and benefits of both flood and sprinkler irrigation for the producer, nearby producers, and the surrounding watershed and ecosystems. Where producers may be interested in maintaining flood irrigation, and where a mix of irrigation methods may contribute to shared watershed goals, e.g. bolstering aquifer recharge or maintaining migratory bird habitat, producers could be incentivized to offset some of the challenges to sustaining flood irrigation such as the significant time and labor needs. 


\section{CASE STUDY 3:}

Maintenance of diverse irrigation methods to optimize water supply in Gold Creek, MT

The Gold Creek watershed provides an interesting example of how maintaining diverse irrigation methods within a watershed can optimize water supply and benefit agriculture and aquatic ecosystems.

Gold Creek is a tributary of the Upper Clark Fork River which originates in the Flint Creek Range and flows 15 miles to its confluence with the Upper Clark Fork between Drummond and Deer Lodge. The agricultural mosaic in Gold Creek consists of six to seven larger ranches and a few smaller ranches, which were all flood irrigated until the late 2000s. During flood irrigation, flow in the lower end of the creek was often reduced to a trickle from mid-summer to early fall, and two stretches of Gold Creek were frequently dewatered during the summer months. One of the largest flood-irrigated ranches in the valley sits at the top of the watershed; return flow from this ranch and other smaller flood-irrigated ranches in the middle of the watershed discharges to the creek about three miles from the confluence. With the whole valley in flood irrigation, this additional streamflow was largely diverted by lower irrigators, and the final half mile of Gold Creek was regularly dewatered, disconnecting it from the Clark Fork River. Tributary mouths are ecologically critical areas, as they allow fish access to spawning grounds and cold water refugia essential for their survival. Disconnection of tributaries from mainstem rivers, particularly during warm, low flow months and spawning season, can be catastrophic for local fish populations.

In 2007 and 2008, two of the larger ranches on the lower end of the creek converted to center pivots. The ranch with the last two diversions on

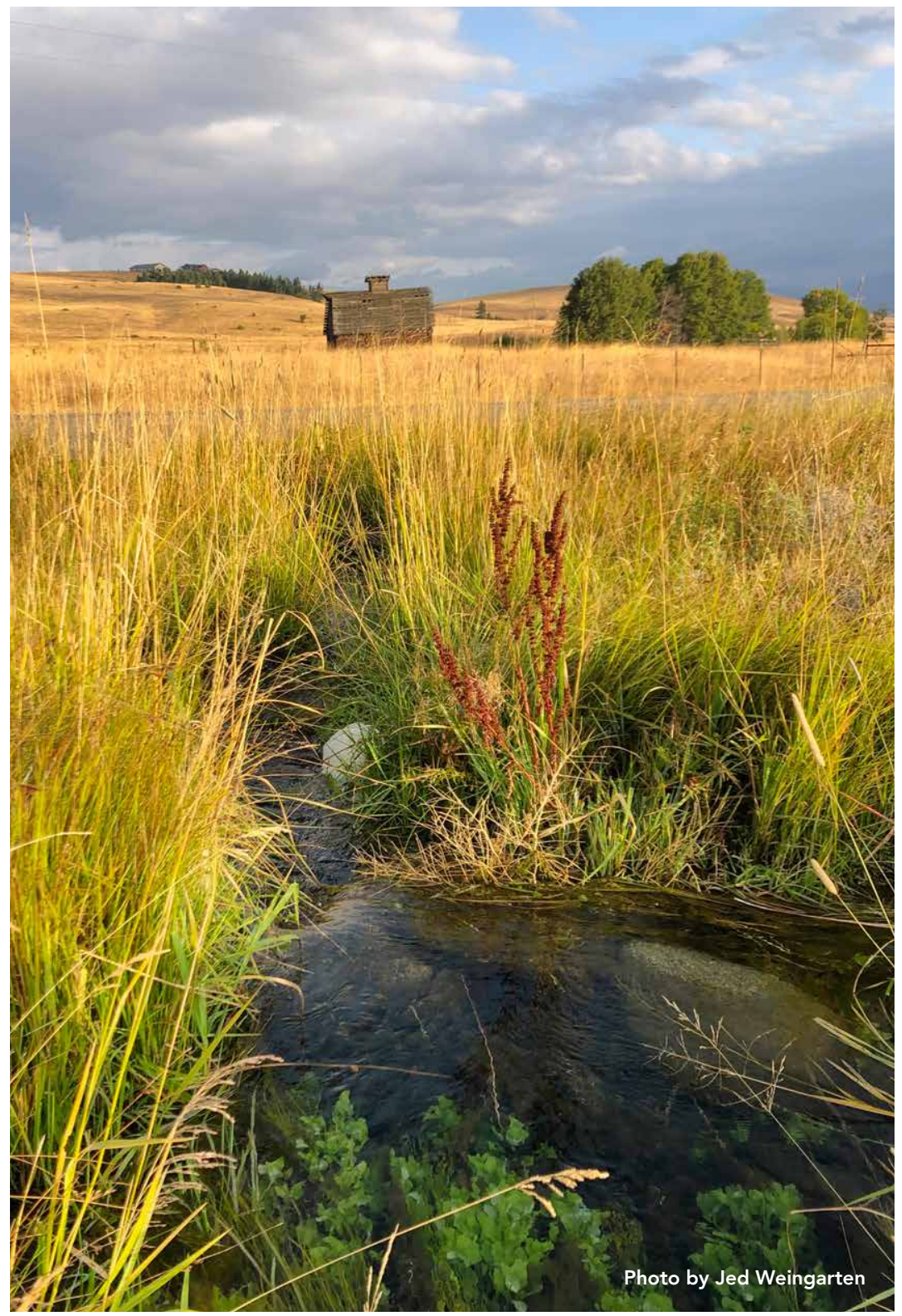

the creek switched to pipe-supplied center pivots, requiring approximately one-quarter the amount of water previously diverted to the operation. Irrigators at the middle and upper end of the watershed continued to flood irrigate, providing significant groundwater recharge upstream. Now, with consistent return flow contributions from upper Gold Creek and the lower ranches diverting significantly less water, streamflow of $10 \mathrm{cfs}$ or more is consistently maintained in the last three miles of the creek. Increased streamflow, in conjunction with riparian fencing, fish screens on diversions, and offstream stock water development, is expected to lead to healthier riparian areas and an improved fishery.

While this exact scenario may not be applicable in other watersheds due to site-specific geology and geography, the general concept is worth consideration as a way to optimize water supply benefits across a watershed. 


\section{Constraints and Opportunities Related to Supporting Aquifer Recharge (Goal 2)}

\section{CONSTRAINT 2A: Infrastructure and operations}

The feasibility of using different irrigation methods on a single farm across an irrigation season may be limited by the challenges of maintaining irrigation equipment, conveyance infrastructure, landscape topography compatible with multiple methods, and labor costs. In addition, if the goal is to use canal infrastructure before and after the irrigation season to support aquifer recharge, annual maintenance that generally takes place during the same timeframe would have to be accommodated, and restoration of defunct canal infrastructure might be necessary.

\section{CONSTRAINT 2B: Period of use}

Nearly all irrigation water rights in Montana have periods of diversion that fall between April $1^{\text {st }}$ and October $31^{\text {st }}$, based on the typical growing season. Although water users can vary their periods of use as long as the dates fall within their periods of diversion, they cannot change the periods of diversion under current Montana law because of the potential increase in water use. As the growing season lengthens and snowpack runs off earlier in the spring, rigid periods of diversion may become problematic. Irrigation water rights are some of the oldest water rights in the state, many with priority dates in the mid-to-late 1800s to early 1900s. This means that modern-day irrigators are constrained by water rights predicated on climate conditions from well over a century ago. Within the Prior Appropriation context, addressing the rigidity of the system or adjusting periods of diversion and use based on current climate conditions could enable strategies such as capturing high spring flows in irrigation canals or irrigating crops earlier or later in the growing season. ${ }^{n}$

\section{CONSTRAINT 2C: Beneficial use and aquifer recharge}

In Montana statute, aquifer recharge is defined as the controlled addition of water to replenish the aquifer, with the sole purpose of offsetting adverse effects from surface water depletions. Aquifer storage and recovery (ASR) projects are defined as the use of an aquifer to temporarily store water through various means such as surface spreading or drain fields, and water can be pumped back out or can "naturally drain away for a beneficial use." It may therefore be possible for an ASR appropriation to be used to support fish and wildlife by augmenting stream flow in the late summer. Some basins that are closed to further water appropriation have highwater year exceptions to closures, and water during these years could theoretically be used for ASR projects that support fish and wildlife or some other beneficial use.
Recharge strategies using infrastructure and practices already in place, such as running canals pre- or postirrigation season, might be considered "incidental" recharge and could take place under existing water rights. It is typically understood that water will be diverted into ditch systems before the irrigation season to "prime" the system; thus, expanding this practice to create additional incidental recharge may be feasible under current policy. In contrast, strategies that require new infrastructure or practices, such as infiltration galleries, would not likely qualify as "incidental" uses of water and may be subject to greater policy hurdles and water permitting requirements.

For situations where new water permits are required, current permit complexities and restrictions could be addressed to enable broader use of ASR. Water available under existing rights could also be used more widely for aquifer recharge given increased flexibility in policy (within a Prior Appropriation context) and greater efficiency in the water right change process. For example, surface water or wetland restoration do not generally require a water right, as long as water is minimally manipulated; if aquifer recharge could be considered 'groundwater restoration' and could be accomplished with minimal manipulation (i.e., running water through existing irrigation canals pre- and post-season), it could become more broadly feasible. Additionally, although water leasing is typically focused on maintaining instream flows, the use of leased water could be extended to include aquifer recharge.

\section{CONSTRAINT 2D: Scope of incentives for irrigated agriculture}

A number of state and federal agencies offer loans and incentives for irrigators to modernize irrigation systems and equipment (i.e., installing sprinklers) with the goal of improving crop production and conserving water. Yet, given the site-specific costs and benefits of both flood and sprinkler irrigation, innovative incentive programs that support diverse irrigation methods could be considered. Financial support for producers who prefer flood irrigation could, in some watersheds, provide hydrologic, ecological and sociocultural benefits at individual and watershed levels. Research has shown that producer decision-making is motivated by a broad spectrum of factors beyond profit maximization, including maintenance of cultural identity, long-term operational viability, and land management ethics. Incentive programs that consider the diversity of motivators, in addition to offering financial support, may be more effective. ${ }^{5}$

\footnotetext{
${ }^{n}$ Current work at the Regional Hydrology Lab at the University of Montana is simulating the hydrologic impacts of advancing the period of use from April 1 to March 15.
} 


\section{Goal 3: Water Conservation}

In many Montana watersheds, demand for water during late summer often exceeds supply, and many water management strategies are designed with the goal of sustaining water supply or reducing water use. In this context it is important consider actions that could reduce water consumption. Some strategies, such as switching to sprinkler irrigation, alter the timing of water availability and reduce diversions but do not necessarily reduce the amount of water consumed. Reducing water consumption in irrigated agriculture can be achieved by reducing any of these three factors: intended consumptive use (crop use), unintended consumptive use (weed growth and evaporation), or unrecoverable seepage (water that is functionally removed from the watershed by contamination or percolation to inaccessible aquifers; Table 3).

\section{STRATEGY 3A: Irrigation timing and precision}

Irrigation timing involves minimizing evaporation by applying water at times when temperatures and wind speeds may be lower. Low sprinkler heads may also minimize evaporation by applying water closer to the crop. Because evaporation removes water from the farm or watershed without benefitting crop growth, reducing this aspect of consumptive use is a useful strategy. The Montana Mesonet, ${ }^{50}$ a project of the Montana Climate Office, has increased the availability of local weather and soil moisture data by establishing a network of new monitoring sites across the state. This effort can help producers reduce unintended evaporation by reducing unnecessary irrigation.

\section{STRATEGY 3B: Building soil health}

Building healthy soils increases the overall resilience of agricultural systems by reducing erosion, increasing productivity, and increasing nutrient retention. Improving soil health by increasing soil organic matter also increases the water-holding capacity of the soil, which is particularly important for drought resilience. Many practices that improve soil health reduce evaporation from the soil, i.e. conservation or minimum tillage, planting cover crops, and creating soil cover with mulch or crop residues. Rotating or diversifying cropping systems can reduce weed competition, thereby reducing unintended consumption.

\section{STRATEGY 3C: Water leasing for instream flow}

Water leasing changes the beneficial use of existing water rights from irrigation to instream flow for fish and wildlife benefits, and can be an effective management tool in watersheds where dewatering impacts healthy ecosystems. Irrigators can voluntarily lease all or part of their historically diverted water to a third party while still retaining ownership of their water right. Water leasing was established in 1985 when fisheries and other natural values were recognized as a beneficial use of water. Like all other water right changes, leasing is overseen by DNRC and is subject to the same public notice and objection process as other water right changes. Requiring a water right change ensures that other water users have the opportunity to object to any adverse impacts that might occur, yet it is also a limiting factor on the extent of water leasing that currently takes place in Montana.

Water rights can be leased, sold, or changed in Montana. Most water leasing occurs through individual water right owners leasing or selling water directly to another entity, e.g. Montana Department of Fish Wildlife and Park, Trout Unlimited, and the Clark Fork Coalition. Some Western states, such as Colorado, Oregon ${ }^{51,52}$ and California have legal frameworks or programs for temporary water leasing where producers can choose to lease a portion of their water rights temporarily, generally later in the growing season or during drought. This strategy can free up water for other uses and provides producers with alternative income at a time when full-scale crop production might be difficult. Temporary, or shortterm, water leasing is often subject to less regulation than long-term leasing, which may allow it to be applied at broader scales and in times of need, crisis, or uncertainty. The Montana legislature passed a bill $(\mathrm{HB} 37)^{53}$ in 2013 to allow short-term leasing outside of the water right change process; it is uncertain how much this practice was utilized, and the framework expired in 2019.

Water leasing associated with a reduction in irrigated land can be a direct way to reduce consumptive use and maintain water instream to support fisheries and ecosystem processes (Box 3). Leasing is often most impactful on tributary streams where a small amount of additional flow can make the difference between a dry streambed or a functional aquatic ecosystem. Even a flushing flow of leased water as short as 48 hours in duration may benefit fish during critical spawning periods. If leasing takes place in the context of conversion to sprinklers (and reduced diversions), it may result in more water instream at certain times but is unlikely to lead to overall water conservation due to the potential for increased crop consumption (see Paradox of Irrigation Efficiency above). 


\section{CONCLUSIONS}

One of our most important contemporary challenges is balancing the multiple demands for water with an increasingly uncertain supply. Maintaining our rich agricultural heritage and working lands in the face of climate change and shifting demographics will require creative approaches across multiple sectors, informed by hydrologic information, sound policy, and communication among producers and other water users on the ground. Irrigation practices, management, and policy can all play important roles in building successful solutions as we work to sustain Montana's landscapes and communities for future generations.

With this report, we have tried to distill a complex topic that contains considerable nuance, and our intention is not to promote any single type of irrigation method as best practice; clearly, there is no onesize-fits-all solution to our water supply challenges. Our main goal is to emphasize that we need to look carefully at the consequences of any irrigation method or practice, or changes therein, so we can meet our intended water supply goals and avoid unintended outcomes. The best suite of irrigation and water management strategies for a particular watershed will depend on site-specific hydrogeologic, geographic, socio-economic and policy-related characteristics, assessed in the context of watershed-specific needs and objectives.
Critical to understanding irrigation hydrology and building successful place-based strategies is the collection of consistent, reliable, and accessible data: we need to measure our water use and understand our demand; we need to know more about how groundwater and surface water interact; and we need to better understand the socio-economic and policyrelated factors that influence the way water moves through our landscapes and supports our livelihoods. Financial investment into the collection, analysis, and communication of water information will pay dividends in terms of guiding proactive decisions and building water sustainability into the future.

In addition to gathering more information, accuracy and care in how we talk about the pathways and fate of water in irrigated agriculture will create a clearer understanding of the net effects of any changes in practice, i.e., water savings or shifts in the timing and location of water availability. It is also important that we consider the full scope of the hydrologic cycle at both farm and watershed scales when assessing potential actions and outcomes.

Finally, we need productive discussion among policy makers to help shepherd and enhance promising strategies that address changes in climate and population growth and increase water security. We also need willingness and buy-in from stakeholders across jurisdictions and sectors to plan and pursue effective water management strategies. Creating sound solutions among diverse and competing interests begins with communication and succeeds in the context of mutual trust and understanding, which provide the foundation for the critical decisions about water that lie ahead. 


\section{LIST OF CONTRIBUTORS}

Evaluating Irrigation Efficiency is the product of a two-year project and working group led by the Montana Water Center, and it represents the collective knowledge and expertise of the many individuals who participated throughout the process. The project consisted of live and recorded webinars, in-person facilitated meetings, conference presentations, telephone interviews, and an extensive review process. Diverse perspectives enriched project discussion and findings; inclusion in the List of Contributors does not necessarily indicate agreement with the information presented in the publication.

We would like to thank the following individuals for their time and participation in this project:

Rick Allen, University of Idaho

Ginette Abdo, Montana Bureau of Mines and Geology

Heather Barber, Bitterroot Water Forum

Stephen Begley, Montana Fish, Wildlife and Parks

Jennifer Boyer, Working Group Facilitator

Diana Brady, Producer, Musselshell River

Jim Brady, Producer, Musselshell River

Peter Brown, Gallatin Valley Land Trust

Zach Brown, Water Policy Interim

Committee, former member

Andy Brummond, Montana Fish, Wildlife and Parks

Jason Burkenpas, Producer, Gallatin River

Patrick Byorth, Trout Unlimited

Joel Cahoon, Montana State University

Rodney Caldwell, U.S. Geological Survey

Brian Chaffin, University of Montana

Barbara Chilcott, Montana Department of Natural Resources and Conservation

Scott Christiaens, Natural Resources Conservation Service

Bryce Contor, Henry's Fork Foundation; Friends of the Teton River

Anna Crockett, University of Montana John DeArment, Clark Fork Coalition

Michael Downey, Montana Department of Natural Resources and Conservation

Susan Duncan, Producer, Gallatin River

Krista Lee Evans, Blake Creek Project Management

Aaron Fiaschetti, U.S. Geological Survey

Jim Forseth, U.S. Bureau of Reclamation

Bryan Gartland, Montana Department of Natural Resources and Conservation

Andrew Gorder, Clark Fork Coalition

Madeline Gotkowitz, Montana Bureau of Mines and Geology

Jim Hagenbarth, Producer, Big Hole River
Leon Hammond, Deadmans Basin Water Users Association; Musselshell River Water Commissioner

Brett Heitshusen, Montana Department of Agriculture

John Hollenback, Producer, Gold Creek/ Upper Clark Fork River

Erling Juel, Greenfields Irrigation District

Eric Kalsta, Producer, Big Hole River

Eloise Kendy The Nature Conservancy

David Ketchum, Montana Department of Natural Resources and Conservation

Laura Kiehl, Producer, Musselshell River

Jay King, Producer, Musselshell River

Aaron Kolb, Yellowstone Conservation District Council

Nathan Korb, The Nature Conservancy

Valerie Kurth, Montana Department of Natural Resources and Conservation

John LaFave, Montana Bureau of Mines and Geology

Max Ludington, LegacyWorks Group

Ethan Mace, Montana Department of Natural Resources and Conservation

Seth Makepeace, Natural Resources Department of the Confederated Salish and Kootenai Tribes

Alan Maki, Producer, Bitterroot River

Marco Maneta, University of Montana

Alan Martinell, Producer, Red Rock/ Beaverhead River

Will McDowell, Clark Fork Coalition

Michelle McGree, Montana Fish, Wildlife and Parks

Justin Meissner, Natural Resources Conservation Service

Liddi Meredith, Montana Bureau of Mines and Geology

Tom Michalek, RESPEC; Montana Bureau of Mines and Geology

Joy Morris, Intermountain West Joint Venture
Nanette Nelson, Flathead Lake Biological Station

Evan Norman, Department of Natural Resources and Conservation

Laura Nowlin, Producer, Musselshell River; Musselshell Watershed Coalition

Rob Payn, Montana State University

Al Pernichele, Painted Rocks Water Users Association; Bitterroot River Irrigation District Water Commissioner

Randy Pierce, Natural Resources Conservation Service, Retired

Rex Radtke, Producer, Flint Creek/Upper Clark Fork River

Chuck Roloff, Natural Resources Conservation Service

Casey Ryan, Natural Resources Department of the Confederated Salish and Kootenai Tribes

Walt Sales, Producer, Gallatin River; Representative HD 69; Water Policy Interim Committee

Melissa Schaar, Montana Department of Natural Resources and Conservation

Dan Severson, Producer, Bitterroot River

Adam Sigler, Montana State University

Nick Silverman, Adaptive Hydrology

Kristin Sleeper, University of Montana

Andrea Stanley, Montana Department of Natural Resources and Conservation

Kerri Strasheim, Montana Department of Natural Resources and Conservation

Bruce Thomas, Producer, Gold Creek/ Upper Clark Fork River

Dan Triemstra, Producer, Gallatin River

Dan Ueland, Producer, Upper Clark Fork River

Rob Van Kirk, Henry's Fork Foundation

Amy Verbeten, Friends of the Teton River

Ned Zimmerman, Producer, Shields River/ Upper Yellowstone River 
Abandonment - The intentional, prolonged, non-use of a water right, resulting in the loss of the right.

Alluvial - Characterized by loose, unconsolidated soil or sediment deposited by water.

Application efficiency - The ratio of the amount of water consumed by crops to the amount of water applied to a field for irrigation, often expressed as a percentage.

Aquifer - A geological formation or structure that stores and/or transmits water, such as to wells and springs. Use of the term is usually restricted to those water-bearing formations capable of yielding water in sufficient quantity to constitute a usable supply for people's uses.

Base flow - Sustained flow of a stream in the absence of direct surface runoff. It includes natural and human-induced streamflows. Natural base flow is sustained largely by groundwater discharge.

Beneficial use - Defined in Montana as the use of water for the benefit of the appropriator, other persons, or the public, including but not limited to agricultural (including stock water), domestic, fish and wildlife, industrial, irrigation, mining, municipal, power, and recreational uses. A beneficial use also includes the use of water for leasing under special provisions of Montana Codes Annotated 85-2-141.

Closed basin - A term used when no more water rights are being granted in the basin in accordance with citizen petition or by legislation mandate.

Conjunctive use - Planned management of surface water and groundwater resources as an interrelated system.

Consumed fraction - The proportion of diverted or applied irrigation water that is consumed (for intended or unintended purposes) or unable to be recovered for reuse within the hydrologic system of use.

Consumptive use - Water removed from the hydrologic system of interest through evaporation or plant transpiration.

Conveyance - Transfer of water from point of withdrawal/diversion to place of use, often in ditches, canals or pipes.

Conveyance efficiency - The ratio of the amount of water applied to the field to the amount of water diverted for irrigation, often expressed as a percentage.

Diversion - The transfer of water from a stream, lake, aquifer, or other source of water to another watercourse or to the land, as in the case of an irrigation system.
Easement - A legal instrument enabling the giving, selling, taking, or use of certain property rights such as land use, without transfer of title, such as for the passage of utility lines.

Evapotranspiration (ET) - Loss of water from soil evaporation and transpiration of plants. i.e. plant use

Groundwater - Any water beneath the land surface or beneath the bed of a stream, lake, or reservoir, and which is not a part of the surface water. The upper surface of the saturated zone is called the water table.

Groundwater recharge - Movement of surface water to groundwater.

Groundwater discharge - Movement of groundwater to a surface water body.

Headgate - A structure installed at the point of diversion to regulate flow.

Instream flows - Water in streams and rivers that maintains the existing water quality or aquatic resources and associated wildlife and riparian habitat.

Intended consumption - Water evaporated or transpired for the intended purpose, such as crop growth.

Irrigation district - A quasi-public governmental organization created by petition and court decree to operate an irrigation system in a defined area that includes the operation of works, delivery of water, and administration of the organization. It is overseen by a board that is elected by the members of the district.

Irrigation efficiency - The ratio of the amount of water consumed by crops to the amount of water diverted for irrigation, often expressed as a percentage.

Junior water right - Between two or more water rights on a source, a water right that is secondary to an earlier (more senior) water right.

Managed (artificial) recharge - A process through which water is put back into groundwater storage through activities such as irrigation and engineered or natural infiltration galleries.

Non-recoverable seepage - Seepage from fields or conveyance structures that does not make it to the aquifer or back to surface water or may become too saline or contaminated to be considered viable for reuse.

Non-reusable fraction - The proportion of diverted or applied irrigation water that is not consumed by evapotranspiration, but does not make it to the aquifer or back to surface water or may become too saline or contaminated to be considered viable for reuse.
Period of use - The time period during each year that the holder of a valid water right is allowed to use water.

Place of use - The location where water is used by a water right holder.

Prior Appropriation Doctrine - A legal theory of water law and a system of water rights management which allocates water between users based upon a priority of water use. It is often defined as a water system where "first in time" is "first in right". During dry years, the person with the first right has the first chance to use the available water. The holder of the second right (a junior right) would have the second chance, and so on.

Priority date - The date a water right was first established. The priority date is used to disperse water according to seniority.

Return flow - Defined in Montana as that part of a diverted flow which is applied to irrigated land and is not consumed and returns underground to its original source or another source of water, and to which other water users are entitled to a continuation of, as part of their water right. Return flow results from use and not from water carried on the surface in ditches and returned to the stream. Reusable fraction - The proportion of diverted or applied irrigation water that is not consumed and that becomes available for reuse within the hydrologic system in question. Runoff - The flow of water over the land surface and eventually in stream channels typically as a function of precipitation, snowmelt, spring discharge, or excess irrigation water.

Seepage - Water that moves from the surface to groundwater through porous soils. Senior water right - Between two or more water rights on a source, the water right with the earliest priority date.

Surface water - Water above the surface of the land including, but not limited to, lakes, rivers, streams, wetlands, wastewater, flood water, and ponds.

Unintended consumption - Water evaporated or transpired for unintended purposes - for example evaporation from fields or water surfaces, weeds, ditch vegetation, etc.

Water budget - An accounting of the inflows, storage, and outflows of water to and from a system.

Water right (or appropriation right) The right to put water to a beneficial use.

Water table - The top of the water surface in the saturated part of an aquifer. 
1. Montana Department of Natural Resources and Conservation (DNRC). 2015. A Watershed Approach to the 2015 Montana State Water Plan. http://dnrc.mt.gov/divisions/water/ management/docs/state-water-plan/2015_mt_water_plan.pdf

2. Dieter, C. A., Linsey, K. S., Caldwell, R. R., Harris, M. A., Ivahnenko, T. I., Lovelace, J. K., Maupin, M. A., and Barber, N. L., 2018, Estimated Use of Water in the United States County-Level Data for 2015 (ver. 2.0, June 2018): U.S. Geological Survey data release. https://doi.org/10.5066/F7TB15V5.

3. Montana Annual Bulletin, 2019, USDA, National Agricultural Statistics Service

4. Irrigating with Limited Water Supplies: A practical guide to choosing crops well-suited to limited irrigation, Montana State University Extension, Water Quality Program, EB169 116/GM 1000 3/06. http://region8water.colostate.edu/PDFs/ Irrigating\%20with\%20Limited\%20Water\%20Supplies.pdf

5. Sketch, M., Dayer, A. A., \& Metcalf, A. L. (2020). Western Ranchers' Perspectives on Enablers and Constraints to Flood Irrigation. Rangeland Ecology \& Management, 73(2), 285-296. https://doi.org/10.1016/j.rama.2019.12.003

6. Ward, Frank A., and Manuel Pulido-Velazquez. Water conservation in irrigation can increase water use. Proceedings of the National Academy of Sciences 105.47 (2008): 18215-18220. www.pnas.org/cgi/doi/10.1073/pnas.0805554104

7. Scott, C. A., Vicuña, S., Blanco-Gutiérrez, I., Meza, F., \& Varela-Ortega, C. (2014). Irrigation efficiency and water-policy implications for river basin resilience. Hydrology and Earth System Sciences, 18(4), 1339. https://doi.org/10.5194/hess-18$1339-2014$

8. Perry, C., Steduto, P., \& Karajeh, F. (2017). Does improved irrigation technology save water? A review of the evidence. Food and Agriculture Organization of the United Nations, Cairo, 42.

9. Grafton, R. Q., Williams, J., Perry, C. J., Molle, F., Ringler, C., Steduto, P., ... \& Allen, R. G. (2018). The paradox of irrigation efficiency. Science, 361(6404), 748-750. https://doi. org/10.1126/science.aat9314

10. Vanderhoof, M. K., Christensen, J. R., \& Alexander, L. C. (2019). Influence of multi-decadal land use, irrigation practices and climate on riparian corridors across the Upper Missouri River headwaters basin, Montana. Hydrology and Earth System Sciences, 23(10), 4269-4292. https://doi.org/10.5194/hess-234269-2019

11. Venn, B. J., Johnson, D. W., \& Pochop, L. O. (2004). Hydrologic impacts due to changes in conveyance and conversion from flood to sprinkler irrigation practices. Journal of irrigation and drainage engineering, 130(3), 192-200. https://doi.org/10.1061/ (ASCE)0733-9437(2004)130:3(192)

12. Remote-Sensing-Based Comparison of Water Consumption by Drip-Irrigated versus Flood-Irrigated Fields Deming, New Mexico, March 13, 2013 IINestlDatalProjects\NMISC. M001.MSA_Deming_ET\Deliverables\Final Report\Final Report_03-13-2013.docx
13. Pfeiffer, L., \& Lin, C. Y. C. (2014). Does efficient irrigation technology lead to reduced groundwater extraction? Empirical evidence. Journal of Environmental Economics and Management, 67(2), 189-208. http://dx.doi.org/10.1016/j. jeem.2013.12.002

14. Stanley, A. and Roberts, M. (2008). Report to Water Policy Interim Committee, "State Funding for Irrigation in Montana and Consequences of Converting from Flood to Sprinkler Irrigation".

15. Montana Trout Unlimited v. MONTANA DNRC, 133 P.3d 224, 2006 M.T. 72, 331 Mont. 483 (2006).

16. Allen, R. G., Clemmens, A. J., \& Willardson, L. S. (2005). Agrohydrology and irrigation efficiency. ICID Working Group Water and Crops.

17. Perry, C. (2007). Efficient irrigation; inefficient communication; flawed recommendations. Irrigation and Drainage: The journal of the International Commission on Irrigation and Drainage, 56(4), 367-378. https://doi.org/10.1007/s00271-007-0060-5

18. Richter, B. D., Brown, J. D., DiBenedetto, R., Gorsky, A., Keenan, E., Madray, C., ... \& Ryu, S. (2017). Opportunities for saving and reallocating agricultural water to alleviate water scarcity. Water Policy, 19(5), 886-907. https://doi.org/10.2166/ wp.2017.143

19. Lankford, B. (2006). Localising irrigation efficiency. Irrigation and Drainage: The journal of the International Commission on Irrigation and Drainage, 55(4), 345-362. https://doi. org/10.1002/ird.270

20. Linstead, C. (2018). The contribution of improvements in irrigation efficiency to environmental flows. Frontiers in Environmental Science, 6, 48. https://doi.org/10.3389/ fenvs.2018.00048

21. Willardson, L. S., Allen, R. G., \& Frederiksen, H. D. (1994, October). Elimination of irrigation efficiencies. In Acta 13th Tech. Conf. USCID. Denver, CO, EEUU (pp. 19-22).

22. Kendy, E. and Bredehoeft, J. D., 2006, Transient effects of groundwater pumping and surface-water-irrigation returns on streamflow. Water Resources Research, vol. 42. https://doi. org/10.1029/2005WR004792

23. Peck, D. E., McLeod, D. M., Hewlett, J. P., \& Lovvorn, J. R. (2004). Irrigation-dependent wetlands versus instream flow enhancement: economics of water transfers from agriculture to wildlife uses. Environmental management, 34(6), 842-855.

24. Donnelly, J. P., Naugle, D. E., Collins, D. P., Dugger, B. D., Allred, B. W., Tack, J. D., \& Dreitz, V. J. (2019). Synchronizing conservation to seasonal wetland hydrology and waterbird migration in semi-arid landscapes. Ecosphere, 10(6), e02758. https://doi.org/10.1002/ecs2.2758

25. Poff, N. L., Allan, J. D., Bain, M. B., Karr, J. R., Prestegaard, K. L., Richter, B. D., ... \& Stromberg, J. C. (1997). The natural flow regime. BioScience, 47(11), 769-784. 
26. Whitlock, C., Cross, W., Maxwell, B., Silverman, N., \& Wade, A. A. (2017). Montana climate assessment. Montana Institute on Ecosystems, Montana State University, and University of Montana, Bozeman and Missoula, Montana, USA. https://doi. org/10.15788/m2ww8w

27. Lytle, D. A., and N. L. Poff. 2004. Adaptation to natural flow regimes. Trends in ecology \& evolution 19:94-100. https://doi. org/10.1016/j.tree.2003.10.002

28. Montana Water Use Act - MCA 85-2 (Title 85, Chapter 2)

29. Sigler, A., and Bauer, B. 2017. Water Rights in Montana: An Overview. Bozeman MT: Montana State University Extension MontGuide.

30. Water Rights in Montana. 2014. Helena and Bozeman MT: Montana Department of Natural Resources and Conservation, Legislative Environmental Quality Council, Montana University System Water Center.

31. Change in Water Appropriation (right) - MCA 85-2-102(6)

32. Toohey v. Campbell, 24 Mont. 13, 60 P. 396 (1900)

33. MacDonnell, L. J. (2011). Montana v. Wyoming: Sprinklers, irrigation water use efficiency and the doctrine of recapture. Golden Gate U. Envtl. LJ, 5, 265. http://digitalcommons.law. ggu.edu/gguelj/vol5/iss2/

34. Book, D. E. (2013). Analysis of Yellowstone River Compact Article V.A.

35. Montana v. Wyoming and North Dakota, 555 U.S. 968, 129 S. Ct. 480 (2008)

36. Montana v. Wyoming, 563 U.S. 368, 131 S. Ct. 1765, 179 L. Ed. 2d 799 (2011)

37. Richter, B. (2014). Chasing water: a guide for moving from scarcity to sustainability. Island press.

38. Blackfoot Drought Response: https://blackfootchallenge.org/ droughtresponse/

39. Big Hole Drought Response: https://bhwc.org/river-conditions/

40. Jefferson River Drought Response: http://jeffersonriverwc.com/ drought/

41. Anderson, M. C., Allen, R. G., Morse, A., \& Kustas, W. P. (2012). Use of Landsat thermal imagery in monitoring evapotranspiration and managing water resources. Remote Sensing of Environment, 122, 50-65. https://doi.org/10.1016/j. rse.2011.08.025

42. Ketchum, D. and Heffner, J. (2018). Estimating Agricultural Irrigation Water Use and Efficiency in Montana, Final Technical Completion Report, Montana Department of Natural Resources and Conservation.

43. https://www.usgs.gov/centers/wy-mt-water/science/verificationdataset-irrigation-status-agricultural-lands-montana?qt-science center_objects=0\#qt-science_center_objects

44. Water Right Abandonment - MCA 85-2-404

45. Kirk, R. W. V., Contor, B. A., Morrisett, C. N., Null, S. E., \& Loibman, A. S. (2020). Potential for Managed Aquifer Recharge to Enhance Fish Habitat in a Regulated River. Water, 12(3), 673. https://doi.org/10.3390/w12030673
46. Meredith, E. and Blais, N., 2019. Quantifying irrigation recharge sources using groundwater modeling. Agricultural Water Management 214 (2019): 9-16. https://doi.org/10.1016/j. agwat.2018.12.032

47. Abdo, G., Butler, J., Myse, T., Wheaton, J., Snyder, D., Metesh, J., and Shaw, G., 2013, Hydrogeologic investigation of the Beaverhead River study area, Beaverhead County, Montana: Montana Bureau of Mines and Geology Open-File Report 637, 132 p. http://mbmg.mtech.edu/pdf-open-files//mbmg637_ beaverhead.pdf

48. Teton Water Users Association, Teton Valley Aquifer Recharge Program, https://tetonwaterusersassociation.org/a-marketapproach

49. Montana Aquatic Resources Services, Channel Migration Easement Program, https://montanaaquaticresources.org/cme/

50. Montana Mesonet, http://climate.umt.edu/mesonet/

51. Kendy, E., Aylward, B., Ziemer, L. S., Richter, B. D., Colby, B. G., Grantham, T. E., ... \& Culp, P. W. (2018). Water transactions for streamflow restoration, water supply reliability, and rural economic vitality in the western United States. JAWRA Journal of the American Water Resources Association, 54(2), 487-504. https://doi.org/10.1111/1752-1688.12619

52. Richter, B. D., Andrews, S., Dahlinghaus, R., Freckmann, G., Ganis, S., Green, J., ... \& Shalvey, J. (2020). Buy Me a River: Purchasing Water Rights to Restore River Flows in the Western USA. JAWRA Journal of the American Water Resources Association, 56(1), 1-15.

53. Administrative Rules of Montana (ARM), Rule: 36.12.2101, Temporary Lease of Appropriation Right (repealed).

54. Dalby, C. E. (Forthcoming). Estimation of the amount of floodirrigated land converted to sprinkler irrigation, in Montana, between mid-twentieth century and 2019. Report to the Montana Water Center, Montana State University. 


\section{FUNDING SOURCES:}

This work was funded through support from the following entities: Montana State University Office of the Vice President of Research, Economic Development, and Graduate Education; the U.S. Geological Survey National Institutes of Water Resources; National Science Foundation MT EPSCoR

This material is based upon work supported in part by the National Science Foundation EPSCoR Cooperative Agreement OIA-1757351. Any opinions, findings, and conclusions or recommendations expressed in this material are those of the author(s) and do not necessarily reflect the views of the National Science Foundation.

Back cover photo by Todd Klassy. 


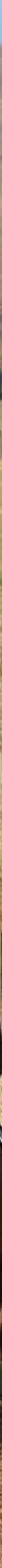

